\title{
Pogressive Collapse Analysis of Multi Storey (G+10) Building by Staad Pro. using Column Removal
}

\author{
SurapuRamlal, PonnanaRamprasad, ChVasudevarao
}

\begin{abstract}
This project presents an attempt to do progressive collapse analysis of multistory $(G+10)$ residential building by STAAD Pro (Structural Analysis and Design Software Application). STAAD Pro is software that helps to analysis and design of low and high-rise buildings and portal frame structures. In this project $G+10 R C$ frame building is analysis statically (linear method) along with Progressive Collapse analysis. In progressive collapse the weight of the building transfers to the neighbour columns in the structure causes to the failure of adjoining members and finally to the failure of partial or whole structure. All the members of the project are analyzed as per Indian codes IS 456:2000, IS 800:2007, and IS 1893:2002 (part1) code using this software. Here the result for is compared between the shear force, bending moment variations value of corner column, Zone1, Zone2, Zone 3 by STAAD Pro. With medium soil type and for Progressive Collapse analysis GSA guidelines are followed.

As per GSA guidelines three column removal cases for each case1, case2, case 3 one at a time has studied, namely Corner column removal, Exterior column removal and interior column removal all at ground floor.
\end{abstract}

Key Words: Progressive collapse analysis, GSA Guidelines, Column removal cases.

\section{INTRODUCTION}

Generally, we consider Self weight, dead loads, Live Loads, wind loads and Earthquake loads for Static and dynamic Analysis. However, after doing static and dynamic analysis also we not sure the structure is safe against local failure due to sudden loss of Column in the structure or abnormal loading like blast of cylinder or due to terrorist attack. So, we have move one step further and check our building against failure of Column at different location in ground floor as per General Service Administration (GSA) guidelines.

Now a day in advance countries, the building is built considering the progressive collapse. Progressive collapse results help to know the behavior of the building generally Progressive Collapse occurs when one of the major load carrying element failed due to some reason such as blast of cylinder or terrorist attack, due to failure of major element load carried by major element is distributed to adjacent elements which increases load on adjacent member more than its capacity and due to which adjacent member also get

Revised Manuscript Received on December 30, 2019.

SurapuRamlal, M.Tech(Ph.D), Department of Civil engineering, HOD, Associate Professor,Aditya Institute of Technology \& Management, Tekkali, Amdhrapradesh.

PonnanaRamprasad, M.Tech(Ph.D), Department of Civil engineering, Assistant Professor, Aditya Institute of Technology \& Management, Tekkali, Amdhrapradesh.

Dr.CH Vasudevarao, Ph.D, Department of Civil engineering, Associate Professor, Aditya Institute of Technology \& Management, Tekkali, Amdhrapradesh. failed and transfers loads to its adjacent member. The process is continuing until all the structure gets failed.

\subsection{GUIDELINES OF GSA}

\subsubsection{Facility security levels (FSL):}

The facility security level resolve to define the norms and process for determining the FSL of a federal facility, which categorizes facilities, depend on the analysis of several security-related facility factors, including its target attractiveness, as well as its value or criticality.

\subsubsection{FSL I \& II:}

Specified the low occupancy and risk level correlated with these types of facilities, progressive collapse design is not preferred for FSL I and II, irrespective of the number of floors.

\subsubsection{FSL III \&IV:}

These Guidelines are relevant to FSL III and IV buildings with four stories or more sustained from the lowest point of exterior grade to the highest point of elevation. Uninhabited floors such as mechanical penthouses or parking shall not be considered a story. It shall implement both the Alternate Path and Redundancy design procedures.

\subsubsection{FSL $V$ :}

These Guidelines are used for all FSL V buildings regardless of number of floors. FSL V facilities shall implement the Alternate Path method for identification of vertical load resisting element removal area. Redundancy design procedures not required for FSL V facilities.

\section{LITRATURE REVIEW}

- S. Mahesh et al $(2014)^{11}$ has published a journal on "Comparison of analysis and design of regular and irregular configuration of multi-Story building in various seismic zones and various types of soils using ETABS and STAAD" to know the behavior of G+11 multi story building of regular and irregular configuration under earth quake is complex and it varies of wind loads are assumed to act simultaneously with earth quake loads. In that paper a residential of $\mathrm{G}+11$ multi story building was studied for earth quake and wind load using ETABS and STAAD PRO V8i. Assuming that material property is linear static and dynamic analysis ware performed. These analyses were 


\section{Pogressive Collapse Analysis of Multi Storey (G+10) Building by Staad Pro. using Column Removal}

carried out by considering different seismic zones and for each zone the behavior was assessed by taking three different types of soils namely Hard, Medium and Soft. Different response like story drift, displacements base shear was plotted for different zones and different types of soils.

- $\quad$ S.S. Patil et al $(2013)^{10}$ has published a journal "Seismic Analysis of High-Rise Building by Response Spectrum Method" to analyzed high rise buildings by response spectrum method using STAADPRO with various conditions of lateral stiffness system. Analysis was done with response spectrum method. Analysis produced the effect of higher modes of vibration \& actual distribution of forces in elastic range in a better way. Test results including base shear, story drift and story deflections were presented and got effective lateral load resisting system.

\section{METHODOLOGY}

To meets the basic requirements such as safety, durability, economy, aesthetic appearance, feasibility, practicability and acceptability following methodology is followed.

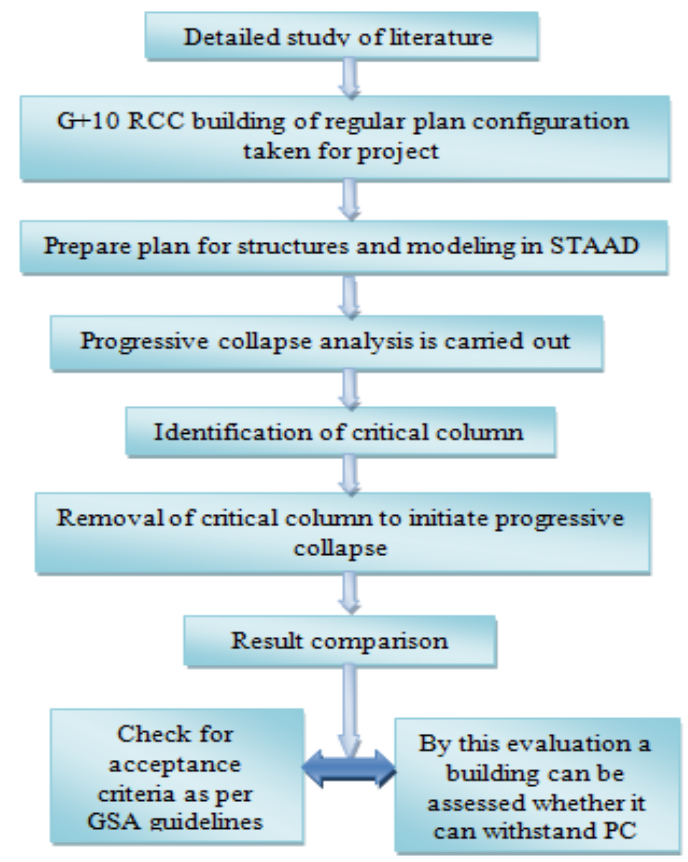

\subsection{Modeling and Loading:}

In STAAD PRO. First Modeling of multistory building which is to be analysis is done. In modeling material to be used to build the structure is defined. The input data used for modeling are as follows:

- Building type: G+10 Residential Building

- Plan area: $25(\mathrm{~m}) * 25(\mathrm{~m})$

- $\quad$ Beam size: $300(\mathrm{~mm}) * 300(\mathrm{~mm})$

- Column size: $350(\mathrm{~mm}) * 350(\mathrm{~mm})$

- Slab thickness: $150 \mathrm{~mm}$

- Typical story height: $3 \mathrm{~m}$

- $\quad$ Bottom story height: $3 \mathrm{~m}$

- Live load, LL: $3 \mathrm{kN} / \mathrm{m}^{2}$ External Wall load: $10.4 \mathrm{KN} / \mathrm{m}$

- Partition and floor finishing load, FL: $1.5 \mathrm{kN} / \mathrm{m}^{2}$
- $\quad$ Soil type: Type II (Medium Soil)

- Materials: M25 and Fe415 Grade

- Soil Bearing Capacity $200 \mathrm{KN} / \mathrm{m}^{2}$

- Earthquake Direction: $\mathrm{X}$ and Y Seismic is defined

- Zone: III -Zone factor 0.16,

- $\quad$ For Progressive Collapse Analysis: In Each Cases further there are 3 Cases they are:

i) Corner Column Removal.

ii) Exterior Column Removal.

iii) Interior Column Removal.

- First a Response Spectrum function is defined for above 4 different Zones with Function Damping Ratio as 0.05 .

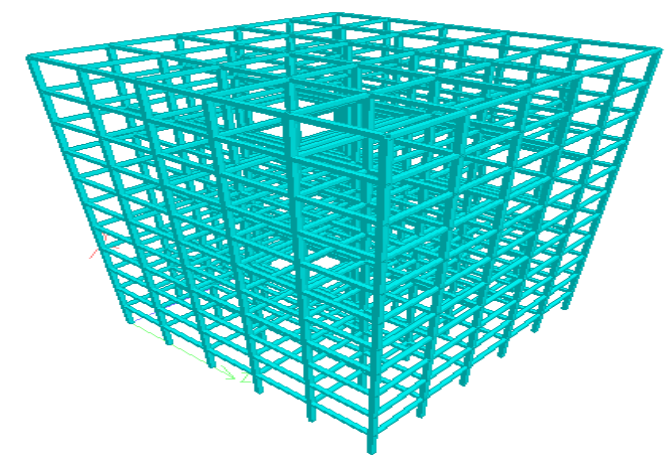

Fig 1.1 G+10 modeling using STAAD PRO.

\section{RESULT AND DISCUSSIONS}

The result obtained for the Shear force, bending moment, for different column removal cases are shown in respective Table and Graph and with discussions.

\subsection{CORNER COLUMN}

SHEAR FORCE VARIATIONS:-

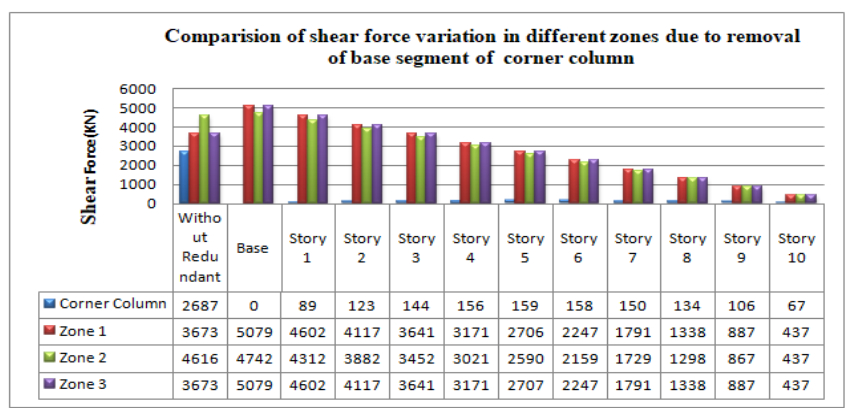

From the above graphical representation, it was observed that the axial load $\mathrm{F}_{\mathrm{y}}$ was increased to maximum by $38.27 \%$, $2.73 \%$ and $38.27 \%$ in zone-1, zone- 2 and zone-3 columns respectively when compared with the base segment was removed.

Due to removal of ground floor column mostly effected zones are zone1 and zone 3. 


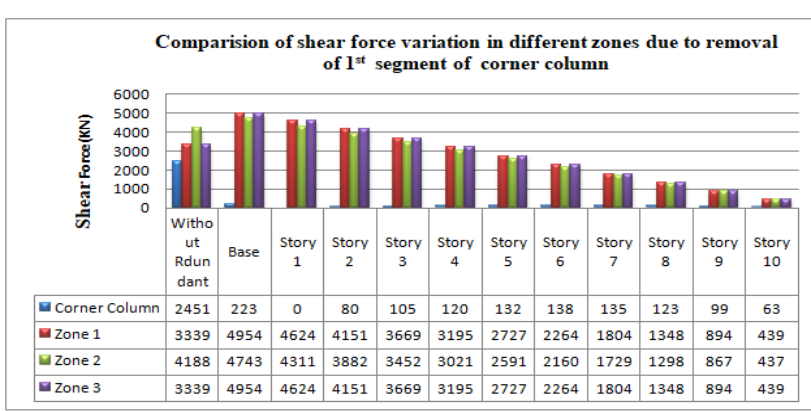

From the above graphical representation, it was observed that the axial load $\mathrm{F}_{\mathrm{y}}$ was increased to maximum by $48.37 \%$, $13.26 \%$ and $48.37 \%$ in zone- 1 , zone- 2 and zone- 3 columns respectively when compared with the $1^{\text {st }}$ segment was removed.

Due to removal of $1^{\text {st }}$ floor column mostly effected zones are zone 1 and zone3.

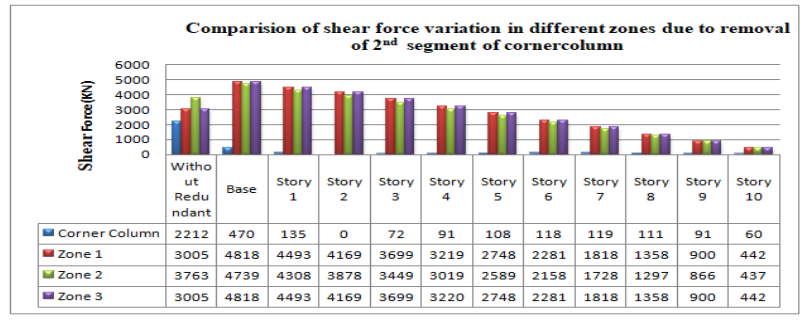

From the above graphical representation, it was observed that the axial load $\mathrm{F}_{\mathrm{y}}$ was increased to maximum by $60.34 \%$, $25.94 \%$ and $60.34 \%$ in zone- 1 , zone- 2 and zone- 3 columns respectively when compared with the $2^{\text {nd }}$ segment was removed.

Due to removal of $2^{\text {nd }}$ floor column mostly effected zones are zone 1 and zone3.

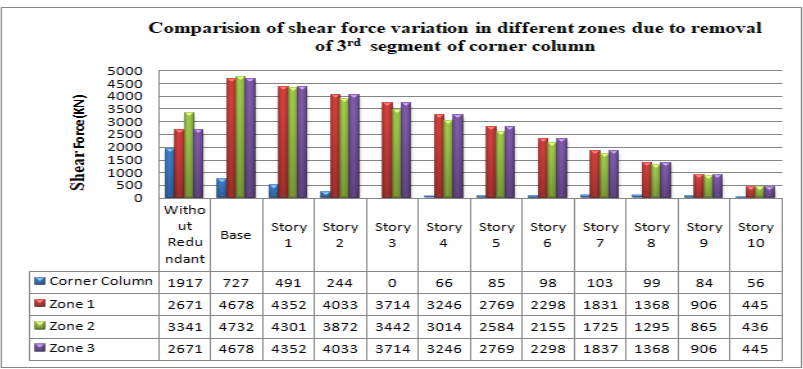

From the above graphical representation, it was observed that the axial load $\mathrm{F}_{\mathrm{y}}$ was increased to maximum by $75.15 \%$, $41.64 \%$ and $75.15 \%$ in zone-1, zone- 2 and zone- 3 columns respectively when compared with the $3^{\text {rd }}$ segment was removed.

Due to removal of $3^{\text {rd }}$ floor column mostly effected zones are zone 1 and zone3.

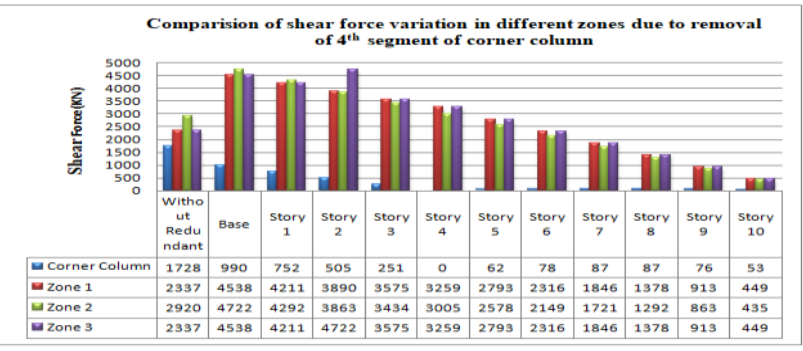

From the above graphical representation, it was observed that the axial load $\mathrm{F}_{\mathrm{y}}$ was increased to maximum by $94.19 \%$, $61.72 \%$ and $94.19 \%$ in zone-1, zone- 2 and zone- 3 columns respectively when compared with the $4^{\text {th }}$ segment was removed.
Due to removal of $4^{\text {th }}$ floor column mostly effected zones are zone1 and zone3.

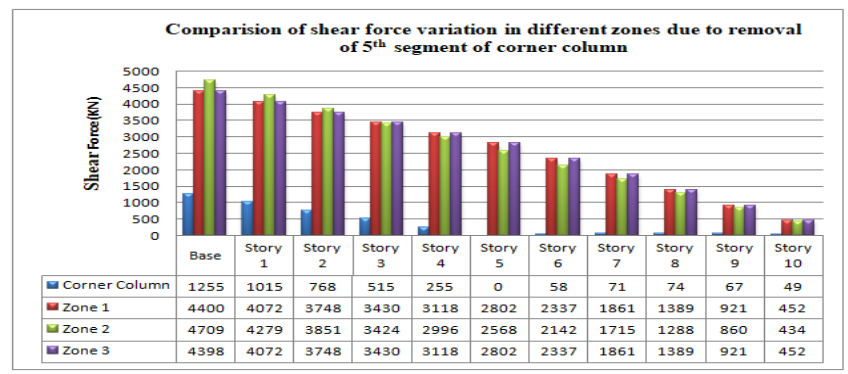

From the above graphical representation, it was observed that the axial load $\mathrm{F}_{\mathrm{y}}$ was increased to maximum by $7.46 \%$, $9.14 \%$ and $7.42 \%$ in zone-1, zone- 2 and zone- 3 columns respectively when compared with the $5^{\text {th }}$ segment was removed.

Due to removal of $5^{\text {th }}$ floor column mostly effected zones are zone2.

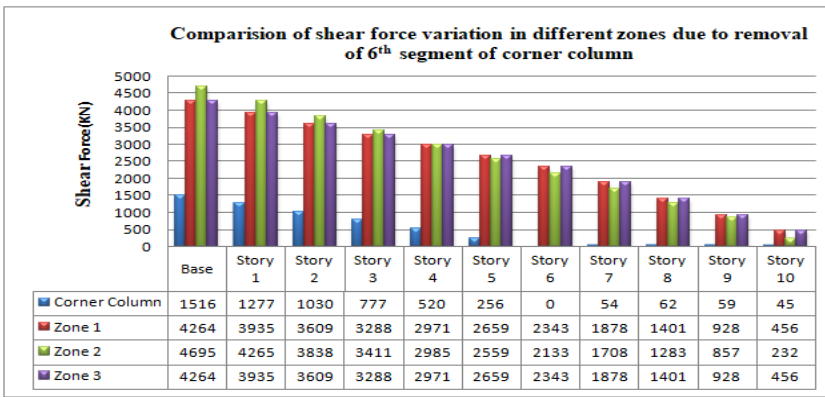

From the above graphical representation, it was observed that the axial load $\mathrm{F}_{\mathrm{y}}$ was increased to maximum by $7.72 \%$, $9.16 \%$ and $7.72 \%$ in zone-1, zone- 2 and zone-3 columns respectively when compared with the $6^{\text {th }}$ segment was removed.

Due to removal of $6^{\text {th }}$ floor column mostly effected zones are zone2.

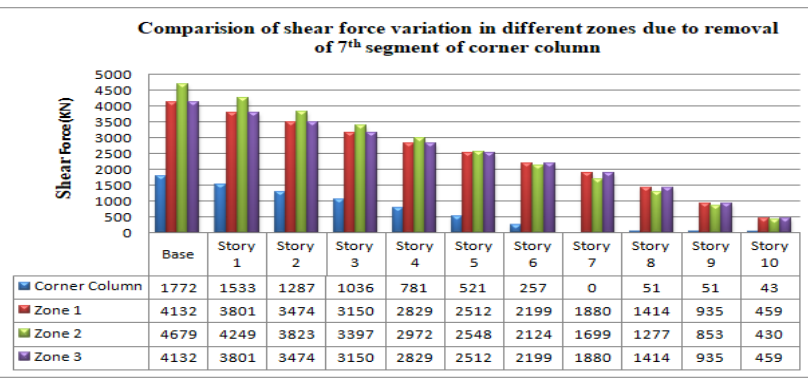

From the above graphical representation, it was observed that the axial load $\mathrm{F}_{\mathrm{y}}$ was increased to maximum by $8.02 \%$, $9.19 \%$ and $8.02 \%$ in zone-1, zone- 2 and zone- 3 columns respectively when compared with the $7^{\text {th }}$ segment was removed.

Due to removal of $7^{\text {th }}$ floor column mostly effected zones are zone2. 


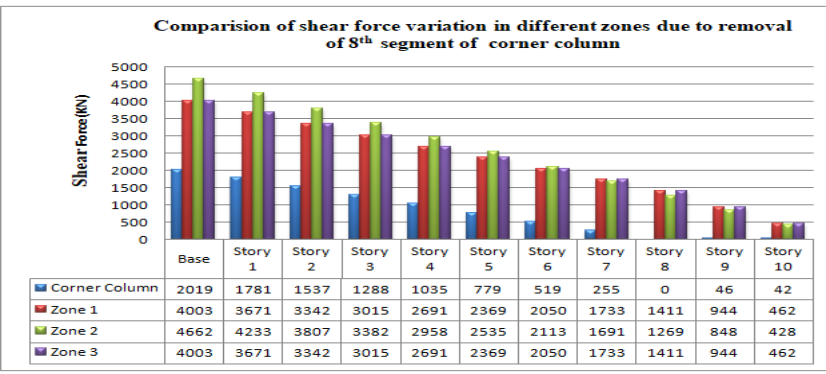

From the above graphical representation, it was observed that the axial load $\mathrm{F}_{\mathrm{y}}$ was increased to maximum by $8.30 \%$, $9.21 \%$ and $8.30 \%$ in zone-1, zone- 2 and zone-3 columns respectively when compared with the $8^{\text {th }}$ segment was removed.

Due to removal of $8^{\text {th }}$ floor column mostly effected zones are zone2.

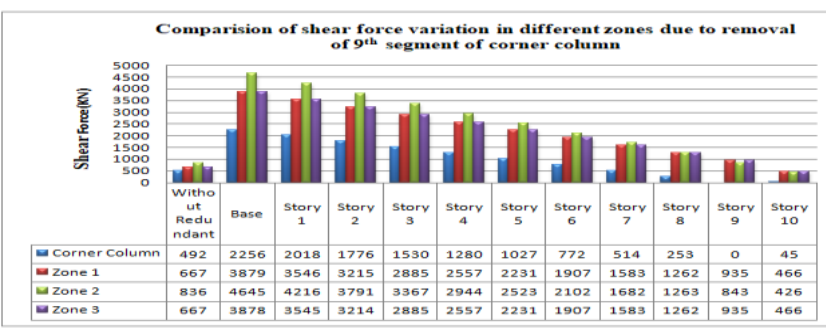

From the above graphical representation, it was observed that the axial load $\mathrm{F}_{\mathrm{y}}$ was increased to maximum by $481.56 \%, 9.14 \%$ and $481.5 \%$ in zone-1, zone- 2 and zone-3 columns respectively when compared with the $9^{\text {th }}$ segment was removed.

Due to removal of $9^{\text {th }}$ floor column mostly effected zones are zone 1 and zone3.

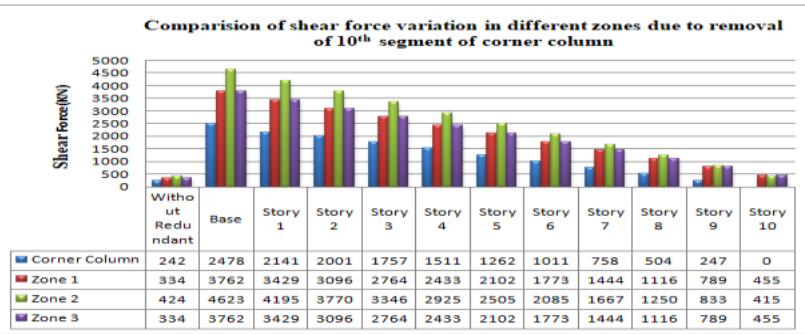

From the above graphical representation, it was observed that the axial load $\mathrm{F}_{\mathrm{y}}$ was increased to maximum by $1026.35 \%, 990.34 \%$ and $1026.35 \%$ in zone-1, zone- 2 and zone- 3 columns respectively when compared with the $10^{\text {th }}$ segment was removed.

Due to removal of $10^{\text {th }}$ floor column mostly effected zones are zone1 and zone3.

\section{BENDING MOMENT VARIATIONS:-}

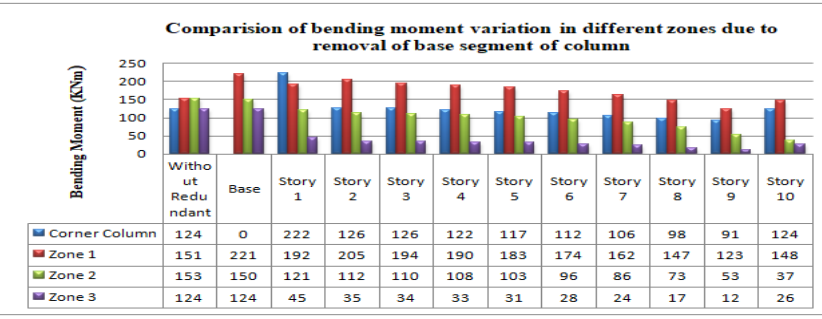

From the above graphical representation, it was observed that the bending moment $\mathrm{M}_{\mathrm{y}}$ was increased to maximum by $46.36 \%, 1.97 \%$ and $0 \%$ in zone-1, zone- 2 and zone- 3 columns respectively when compared with the base segment was removed.
Due to removal of base floor column mostly effected zones are zone1.

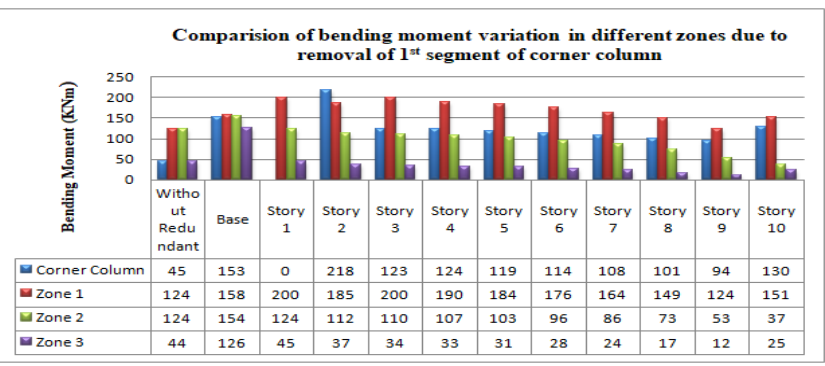

From the above graphical representation, it was observed that the bending moment My was increased to maximum by $27.42 \%, 24.20 \%$ and $186.37 \%$ in zone-1, zone- 2 and zone- 3 columns respectively when compared with the $1^{\text {st }}$ segment was removed.

Due to removal of $1^{\text {st }}$ floor column mostly effected zones are zone3.

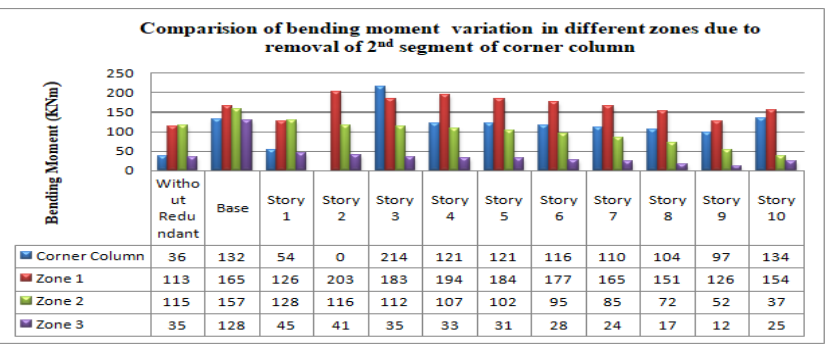

From the above graphical representation, it was observed that the bending moment $\mathrm{M}_{\mathrm{y}}$ was increased to maximum by $46.02 \%, 36.53 \%$ and $265.72 \%$ in zone-1, zone- 2 and zone- 3 columns respectively when compared with the $2^{\text {nd }}$ segment was removed.

Due to removal of $2^{\text {nd }}$ floor column mostly effected zones are zone3.

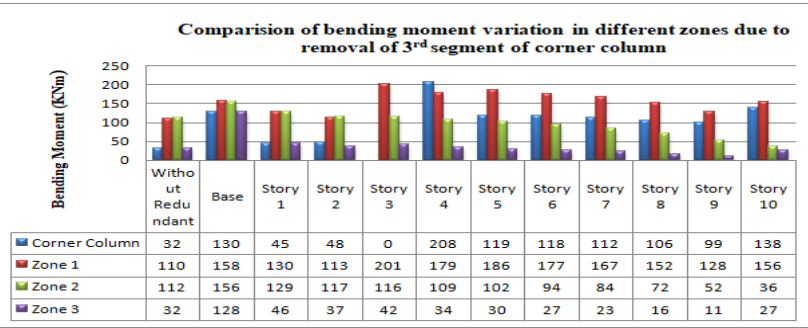

From the above graphical representation, it was observed that the bending moment $\mathrm{M}_{\mathrm{y}}$ was increased to maximum by $43.64 \%, 39.29 \%$ and $300 \%$ in zone-1, zone- 2 and zone- 3 columns respectively when compared with the $3^{\text {rd }}$ segment was removed.

Due to removal of $3^{\text {rd }}$ floor column mostly effected zones are zone3.

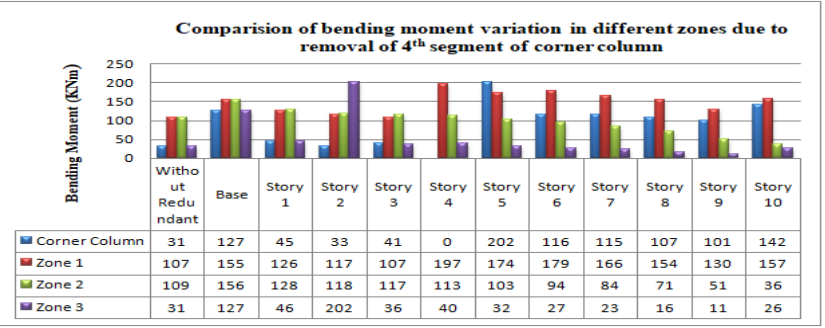

Published By:

Blue Eyes Intelligence Engineering

\& Sciences Publication 
From the above graphical representation, it was observed that the bending moment $\mathrm{M}_{\mathrm{y}}$ was increased to maximum by $44.86 \%, 43.12 \%$ and $309.68 \%$ in zone- 1 , zone- 2 and zone- 3 columns respectively when compared with the $4^{\text {th }}$ segment was removed.

Due to removal of $4^{\text {th }}$ floor column mostly effected zones are zone3.

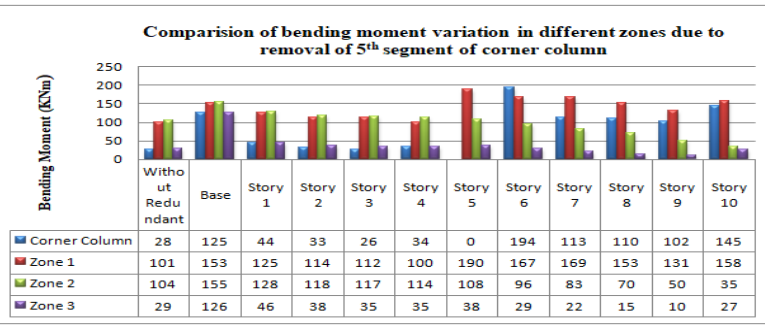

From the above graphical representation, it was observed that the bending moment $\mathrm{M}_{\mathrm{y}}$ was increased to maximum by $51.49 \%, 49.04 \%$ and $334.49 \%$ in zone-1, zone- 2 and zone- 3 columns respectively when compared with the $5^{\text {th }}$ segment was removed.

Due to removal of $5^{\text {th }}$ floor column mostly effected zones are zone3.

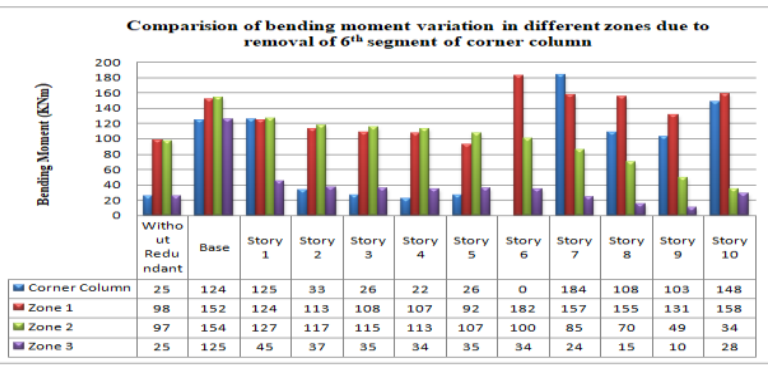

From the above graphical representation, it was observed that the bending moment $\mathrm{M}_{\mathrm{y}}$ was increased to maximum by $55.11 \%, 58.77 \%$ and $400 \%$ in zone-1, zone- 2 and zone-3 columns respectively when compared with the6th segment was removed.

Due to removal of $6^{\text {th }}$ floor column mostly effected zones are zone3.

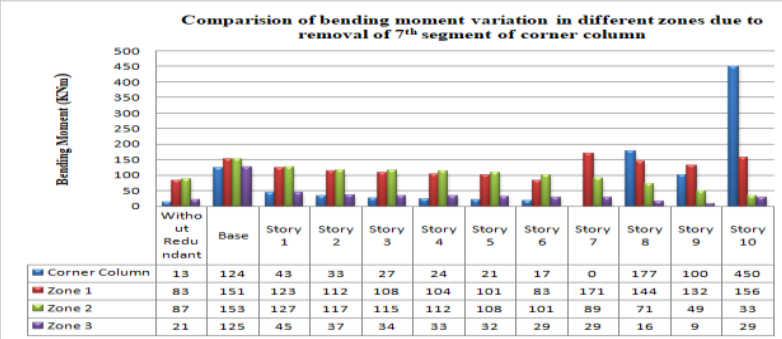

From the above graphical representation, it was observed that the bending moment $\mathrm{M}_{\mathrm{y}}$ was increased to maximum by $81.93 \%, 75.87 \%$ and $495.24 \%$ in zone-1, zone- 2 and zone- 3 columns respectively when compared with the $7^{\text {th }}$ segment was removed.

Due to removal of $7^{\text {th }}$ floor column mostly effected zones are zone3.

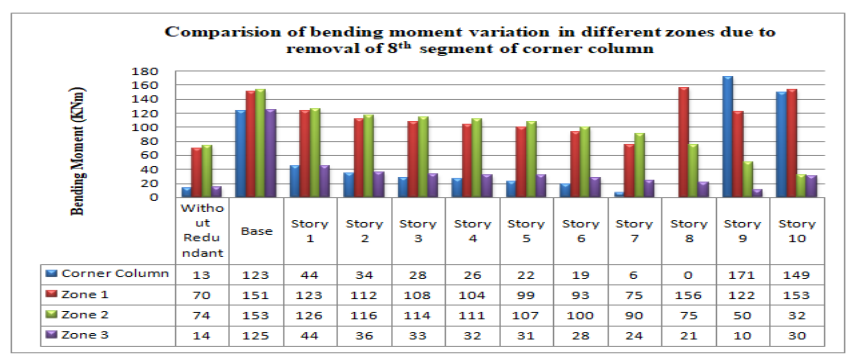

From the above graphical representation, it was observed that the bending moment $\mathrm{M}_{\mathrm{y}}$ was increased to maximum by $55.11 \%, 58.77 \%$ and $400 \%$ in zone-1, zone- 2 and zone-3 columns respectively when compared with the $8^{\text {th }}$ segment was removed.

Due to removal of $8^{\text {th }}$ floor column mostly effected zones are zone3.

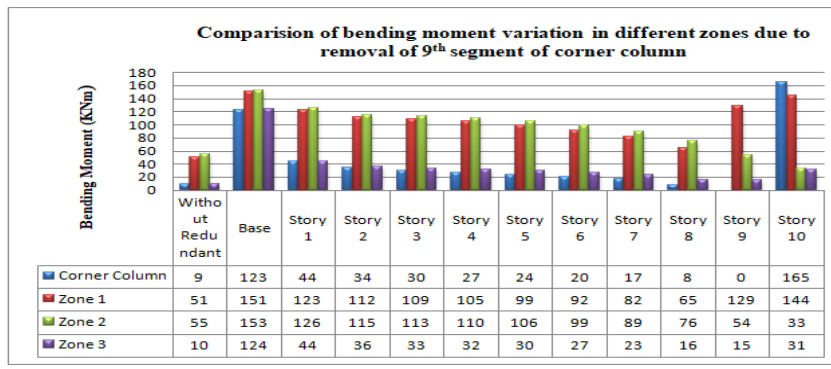

From the above graphical representation, it was observed that the bending moment My was increased to maximum by $196.08 \%, 178.19 \%$ and $1140 \%$ in zone-1, zone-2 and zone-3 columns respectively when compared with the $9^{\text {th }}$ segment was removed.

Due to removal of $9^{\text {th }}$ floor column mostly effected zones are zone 3 .

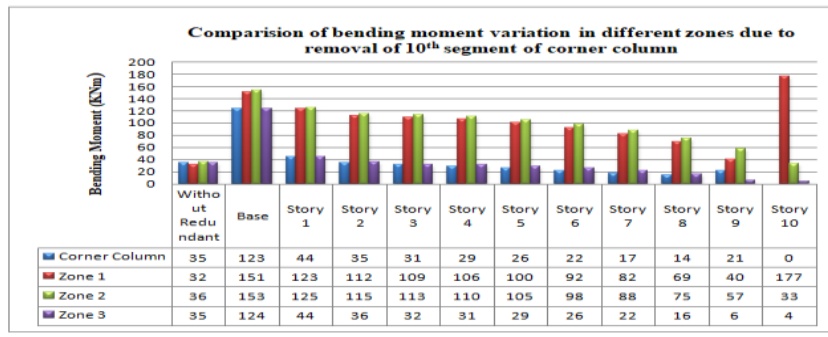

From the above graphical representation, it was observed that the bending moment $\mathrm{M}_{\mathrm{y}}$ was increased to maximum by $371.88 \%, 325 \%$ and $254.29 \%$ in zone-1, zone- 2 and zone- 3 columns respectively when compared with the $10^{\text {th }}$ segment was removed.

Due to removal of $10^{\text {th }}$ floor column mostly effected zones are zone1.

\subsection{EXTERIOR COLUMN}

SHEAR FORCE VARIATIONS:-

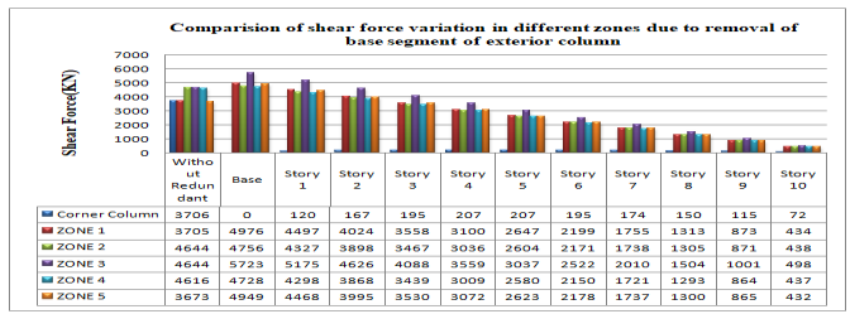


From the above graphical representation, it was observed that the axial load $\mathrm{F}_{\mathrm{y}}$ was increased to maximum by $35.31 \%$, $2.42 \%, 23.24 \%, 2.43 \%$ and $34.74 \%$ in zone-1, zone- 2 , zone3 , zone-4and zone-5 columns respectively when compared with the base segment was removed.

Due to removal of base floor column mostly effected zones are zone1.

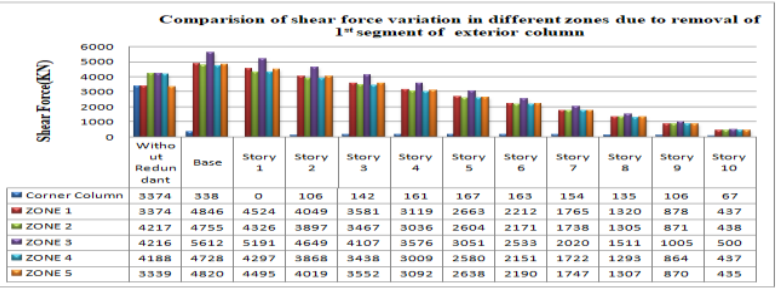

From the above graphical representation, it was observed that the axial load $\mathrm{F}_{\mathrm{y}}$ was increased to maximum by $30.38 \%$, $12.76 \%, 33.12 \%, 12.92 \%$ and $44.39 \%$ in zone-1, zone-2, zone-3, zone-4and zone-5 columns respectively when compared with the $1^{\text {st }}$ segment was removed.

Due to removal of $1^{\text {st }}$ floor column mostly affected zones are zone5.

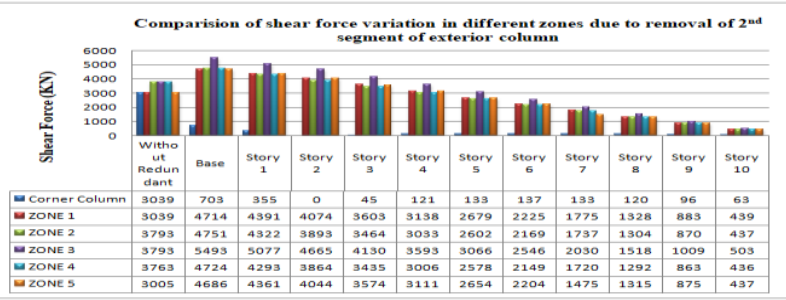

From the above graphical representation, it was observed that the axial load $\mathrm{F}_{\mathrm{y}}$ was increased to maximum by $55.12 \%$, $25.26 \%, 44.82 \%, 25.54 \%$ and $55.95 \%$ in zone-1, zone-2, zone-3, zone-4and zone-5 columns respectively when compared with the $2^{\text {nd }}$ segment was removed.

Due to removal of $2^{\text {nd }}$ floor column mostly effected zones are zone 5 .

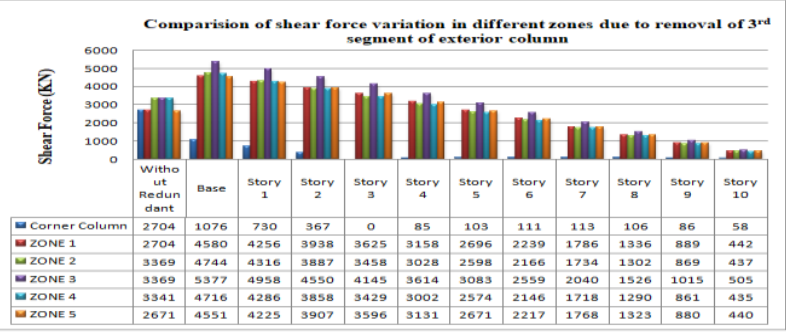

From the above graphical representation, it was observed that the axial load $\mathrm{F}_{\mathrm{y}}$ was increased to maximum by $69.36 \%$, $40.82 \%, 37.35 \%, 41.16 \%$ and $70.39 \%$ in zone-1, zone-2, zone-3, zone-4and zone-5 columns respectively when compared with the $3^{\text {rd }}$ segment was removed.

Due to removal of $3^{\text {rd }}$ floor column mostly effected zones are zone 5 .

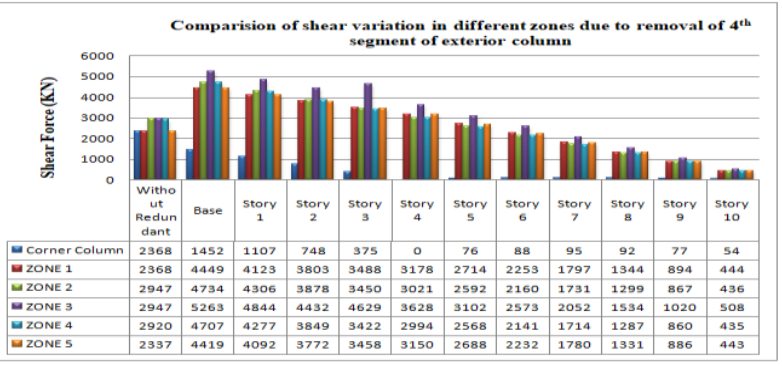

From the above graphical representation, it was observed that the axial load $\mathrm{F}_{\mathrm{y}}$ was increased to maximum by $87.89 \%$,
$60.64 \%, 78.59 \%, 61.20 \%$ and $89.09 \%$ in zone-1, zone-2, zone-3, zone-4and zone-5 columns respectively when compared with the $4^{\text {th }}$ segment was removed.

Due to removal of $4^{\text {th }}$ floor column mostly effected zones are zone 5 .

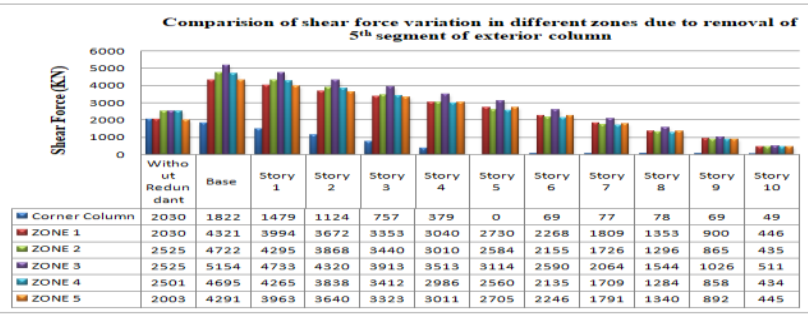

From the above graphical representation, it was observed that the axial load $\mathrm{F}_{\mathrm{y}}$ was increased to maximum by $112.86 \%, 87.01 \%, 104.12 \%, 87.73 \%$ and $114.23 \%$ in zone1 , zone-2, zone-3, zone-4 and zone-5 columns respectively when compared with the 5 th segment was removed.

Due to removal of $5^{\text {th }}$ floor column mostly effected zones are zone 5.

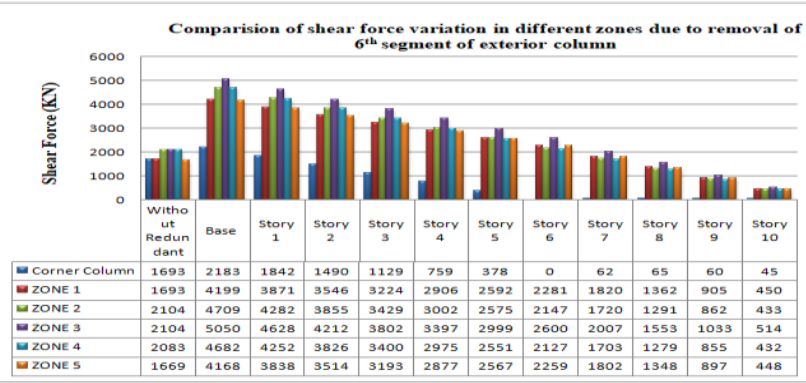

From the above graphical representation, it was observed that the axial load $\mathrm{F}_{\mathrm{y}}$ was increased to maximum by $148.03 \%, 123.82 \%, 140.01 \%, 124.78 \%$ and $149.74 \%$ in zone-1, zone-2, zone-3, zone-4 and zone-5 columns respectively when compared with the $6^{\text {th }}$ segment was removed.

Due to removal of $6^{\text {th }}$ floor column mostly effected zones are zone 5.

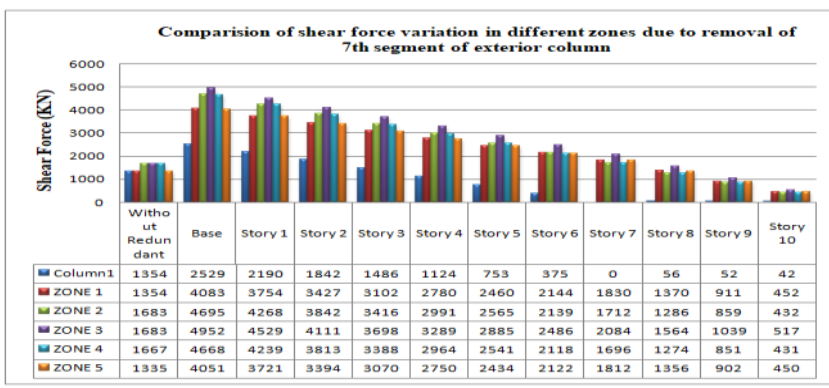

From the above graphical representation, it was observed that the axial load $\mathrm{F}_{\mathrm{y}}$ was increased to maximum by $201.56 \%, 179.97 \%, 194.24 \%, 180.03 \%$ and $203.45 \%$ in zone-1, zone-2, zone-3, zone-4 and zone-5 columns respectively when compared with the $7^{\text {th }}$ segment was removed.

Due to removal of $7^{\text {th }}$ floor column mostly effected zones are zone 5. 


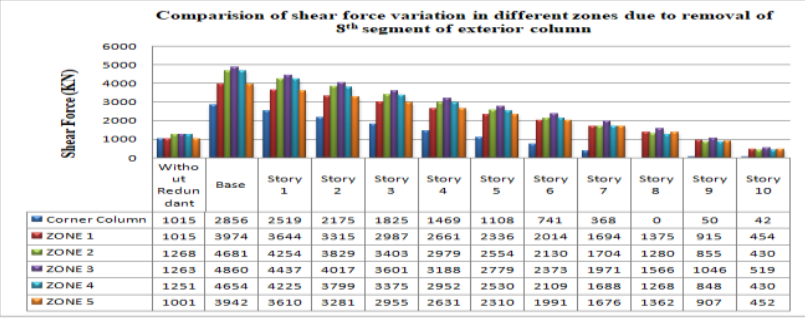

From the above graphical representation, it was observed that the axial load $\mathrm{F}_{\mathrm{y}}$ was increased to maximum by $292.53 \%, 269.25 \%, 284.80 \%, 272.03 \%$ and $293.81 \%$ in zone-1, zone-2, zone-3, zone-4 and zone-5 columns respectively when compared with the8th segment was removed.

Due to removal of $8^{\text {th }}$ floor column mostly effected zones are zone 5.

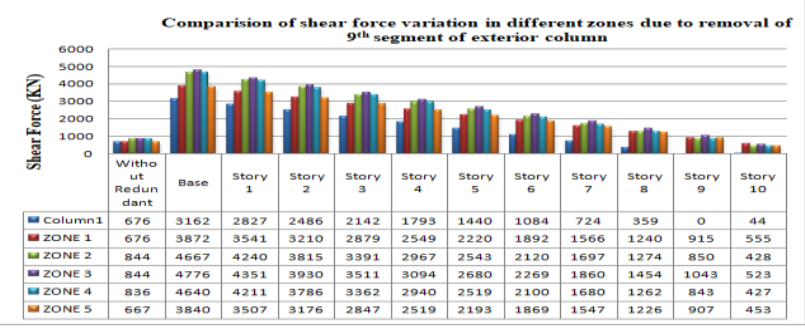

From the above graphical representation, it was observed that the axial load $\mathrm{F}_{\mathrm{y}}$ was increased to maximum by $472.79 \%, 452.97 \%, 465.88 \%, 455.03 \%$ and $475.72 \%$ in zone-1, zone-2, zone-3, zone-4 and zone-5 columns respectively when compared with the $9^{\text {th }}$ segment was removed.

Due to removal of $9^{\text {th }}$ floor column mostly effected zones are zone 5 .

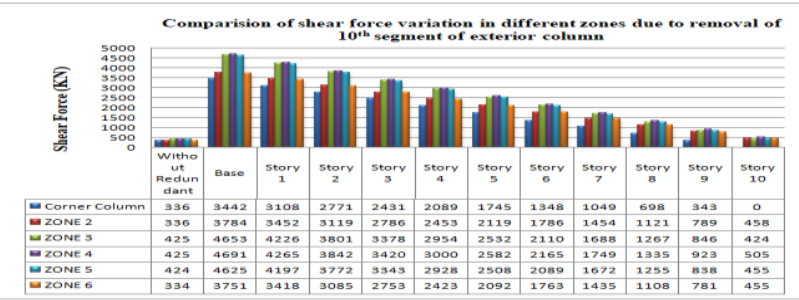

From the above graphical representation, it was observed that the axial load $\mathrm{F}_{\mathrm{y}}$ was increased to maximum by $1026.20 \%, 995.06 \%, 988.24 \%, 990.81 \%$ and $1024.06 \%$ in zone-1, zone-2, zone-3, zone-4 and zone-5 columns respectively when compared with the $10^{\text {th }}$ segment was removed.

Due to removal of $10^{\text {th }}$ floor column mostly effected zones are zone 1.

\section{BENDING MOMENT VARIATIONS:-}

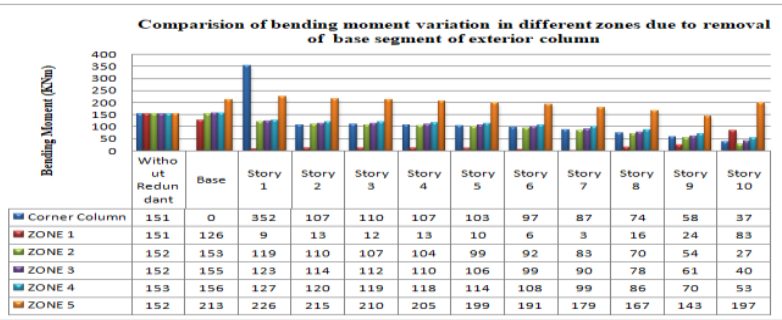

From the above graphical representation, it was observed that the bending moment $\mathrm{M}_{\mathrm{y}}$ was increased to maximum by $16.56 \%, 0.66 \%, 1.98 \%, 1.97 \%$ and $40.14 \%$ in zone-1, zone2, zone-3, zone-4 and zone-5 columns respectively when compared with the base segment was removed.
Due to removal of base floor column mostly effected zones are zone 5.

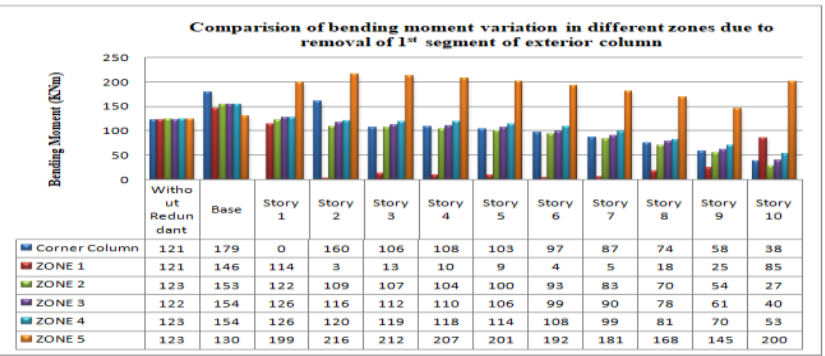

From the above graphical representation, it was observed that the bending moment $\mathrm{M}_{\mathrm{y}}$ was increased to maximum by $20.67 \%, 24.40 \%, 26.23 \%, 25.21 \%$ and $5.70 \%$ in zone-1, zone-2, zone-3, zone-4 and zone-5 columns respectively when compared with the $1^{\text {st }}$ segment was removed.

Due to removal of $1^{\text {st }}$ floor column mostly effected zones are zone 3.

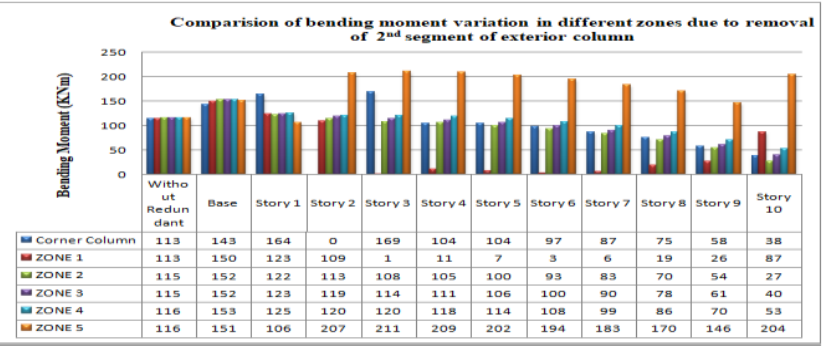

From the above graphical representation, it was observed that the bending moment $\mathrm{M}_{\mathrm{y}}$ was increased to maximum by $20.67 \%, 24.40 \%, 26.23 \%, 25.21 \%$ and $5.70 \%$ in zone-1, zone-2, zone-3, zone-4 and zone-5 columns respectively when compared with the $2^{\text {nd }}$ segment was removed.

Due to removal of $2^{\text {nd }}$ floor column mostly effected zones are zone 3.

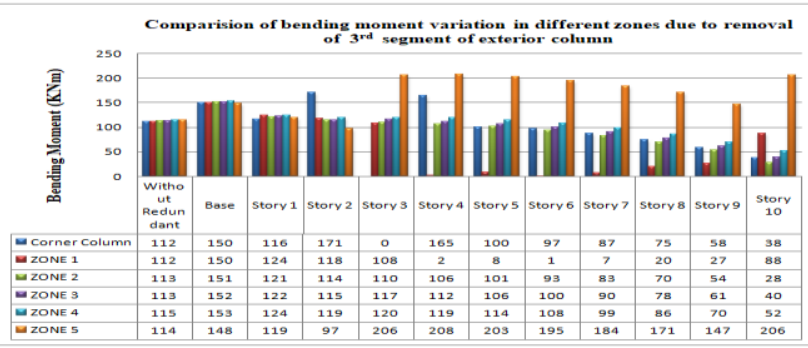

From the above graphical representation, it was observed that the bending moment $\mathrm{M}_{\mathrm{y}}$ was increased to maximum by $33.93 \%, 33.63 \%, 34.52 \%, 33.05 \%$ and $29.83 \%$ in zone-1, zone-2, zone-3, zone-4 and zone-5 columns respectively when compared with the $3^{\text {rd }}$ segment was removed.

Due to removal of $3^{\text {rd }}$ floor column mostly effected zones are zone 3.

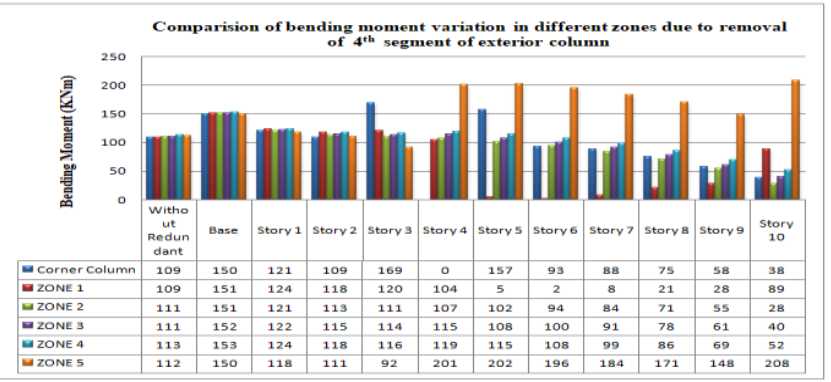

Published By:

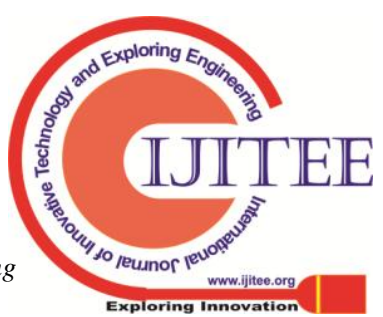


From the above graphical representation, it was observed that the bending moment $\mathrm{M}_{\mathrm{y}}$ was increased to maximum by $38.54 \%, 36.04 \%, 36.94 \%, 35.40 \%$ and $33.93 \%$ in zone-1, zone-2, zone-3, zone-4 and zone-5 columns respectively when compared with the $4^{\text {th }}$ segment was removed.

Due to removal of $4^{\text {th }}$ floor column mostly effected zones are zone 1 .

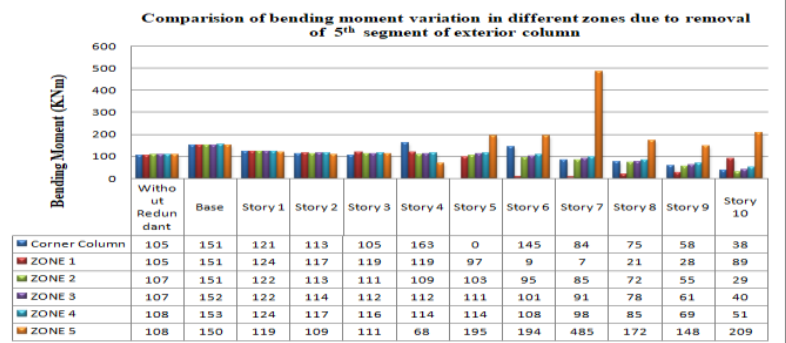

From the above graphical representation, it was observed that the bending moment $\mathrm{M}_{\mathrm{y}}$ was increased to maximum by $43.81 \%, 41.13 \%, 42.06 \%, 41.67 \%$ and $39.89 \%$ in zone-1, zone-2, zone-3, zone-4 and zone-5 columns respectively when compared with the $5^{\text {th }}$ segment was removed.

Due to removal of $5^{\text {th }}$ floor column mostly effected zones are zone 1.

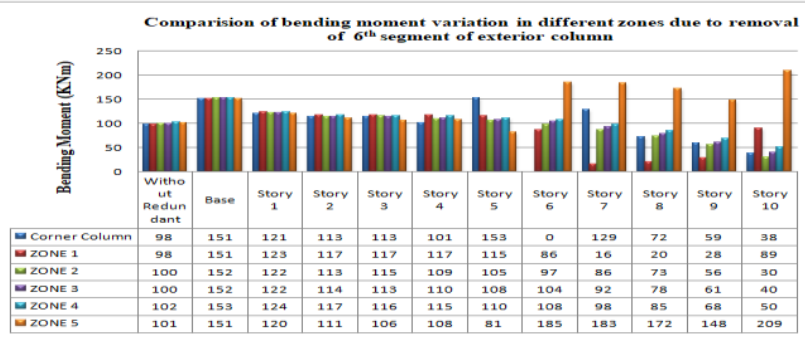

From the above graphical representation, it was observed that the bending moment $\mathrm{M}_{\mathrm{y}}$ was increased to maximum by $54.09 \%, 52 \%, 52 \%, 50 \%$ and $49.51 \%$ in zone-1, zone-2, zone-3, zone-4 and zone-5 columns respectively when compared with the $6^{\text {th }}$ segment was removed.

Due to removal of $6^{\text {th }}$ floor column mostly effected zones are zone 1 .

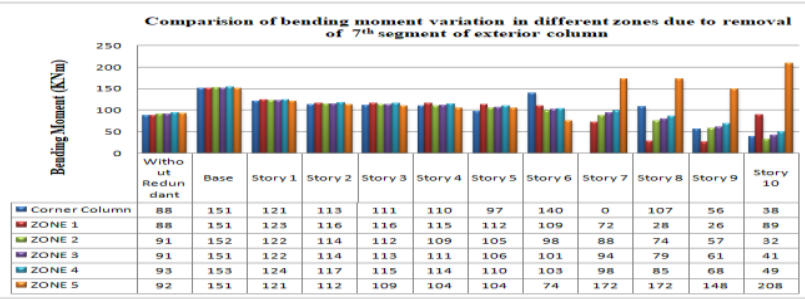

From the above graphical representation, it was observed that the axial load $\mathrm{M}_{\mathrm{y}}$ was increased to maximum by $71.60 \%, 67.04 \%, 65.94 \%, 64.52 \%$ and $64.14 \%$ in zone-1, zone-2, zone-3, zone-4 and zone-5 columns respectively when compared with the CF7 was removed.

Due to removal of $7^{\text {th }}$ floor column mostly effected zones are zone 1.

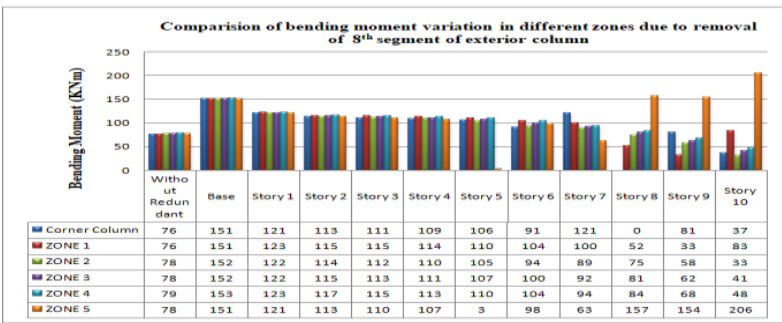

From the above graphical representation, it was observed that the bending moment $\mathrm{M}_{\mathrm{y}}$ was increased to maximum by $96.16 \%, 94.88 \%, 94.88 \%, 93.68 \%$ and $93.59 \%$ in zone-1, zone-2, zone-3, zone-4 and zone-5 columns respectively when compared with the $8^{\text {th }}$ segment was removed.

Due to removal of $8^{\text {th }}$ floor column mostly effected zones are zone 1 .

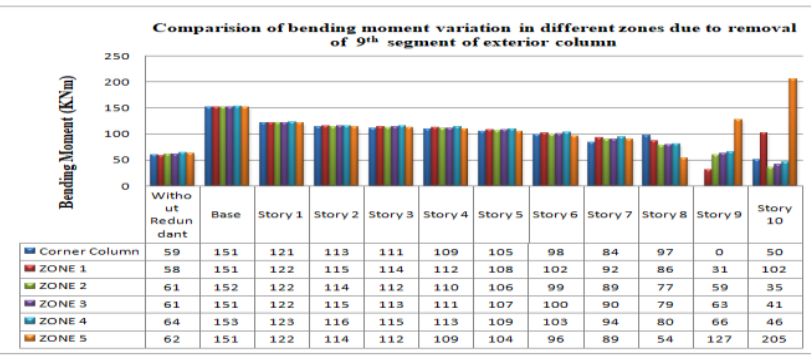

From the above graphical representation, it was observed that the bending moment $\mathrm{M}_{\mathrm{y}}$ was increased to maximum by $160.35 \%, 149.19 \%, 147.55 \%, 139.07 \%$ and $143.55 \%$ in zone-1, zone-2, zone-3, zone-4 and zone-5 columns respectively when compared with the $9^{\text {th }}$ segment was removed.

Due to removal of $9^{\text {th }}$ floor column mostly effected zones are zone 1 .

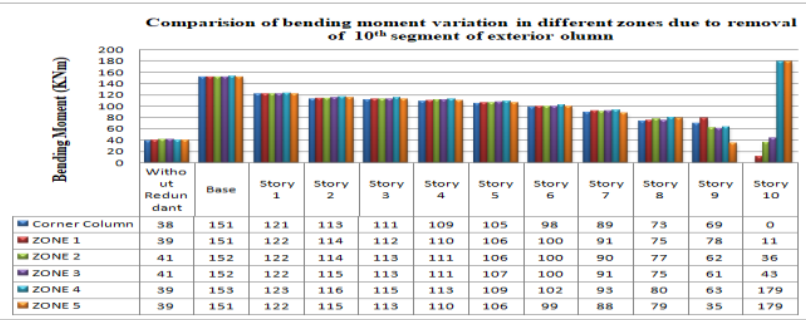

From the above graphical representation, it was observed that the bending moment $\mathrm{M}_{\mathrm{y}}$ was increased to maximum by $287.18 \%, 270.74 \%, 270.74 \%, 292.31 \%$ and $287.18 \%$ in zone-1, zone-2, zone-3, zone-4 and zone-5 columns respectively when compared with the $9^{\text {th }}$ segment was removed.

Due to removal of $9^{\text {th }}$ floor column mostly effected zones are zone 4.

\subsection{INTERIOR COLUMN}

SHEAR FORCE VARIATIONS:-

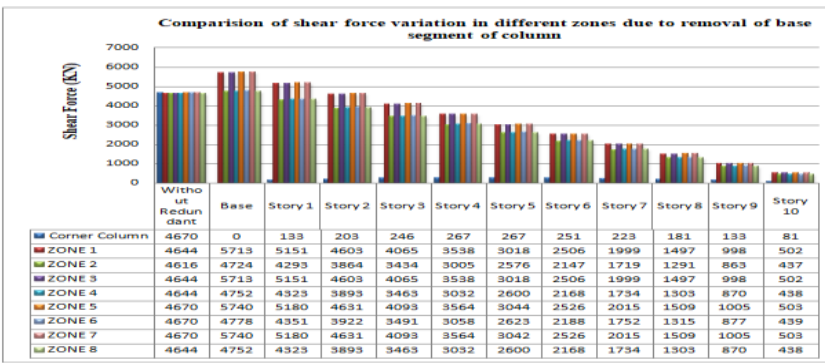

From the above graphical representation, it was observed that the axial load $\mathrm{F}_{\mathrm{y}}$ was increased to maximum by $23.02 \%$, $2.34 \%, 23.02 \%, 2.33 \%, 22.92 \%, 2.32 \%, 22.92 \%$ and $2.33 \%$ in zone- 1 , zone- 2 , zone- 3 , zone- 4 , zone- 5 , zone- 6 , zone- 7 and zone- 8 columns respectively when compared with the base segment was removed.

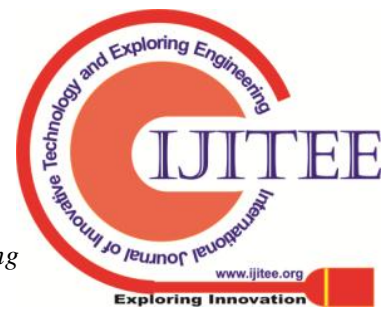


Due to removal of base floor column mostly effected zones are zone 1.

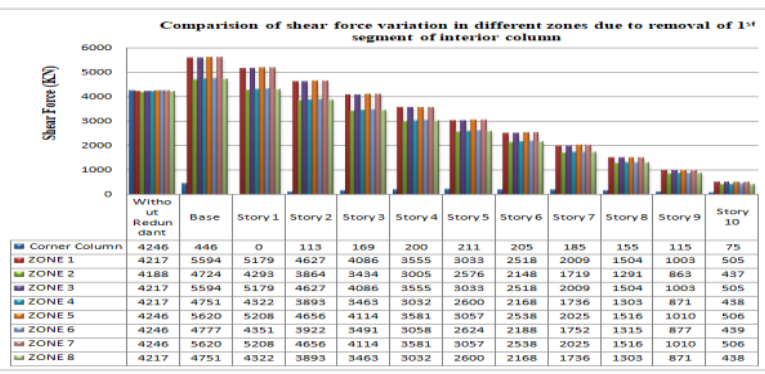

From the above graphical representation, it was observed that the axial load $\mathrm{F}_{\mathrm{y}}$ was increased to maximum by $32.66 \%$, $12.80 \%, \quad 32.66 \%, \quad 12.67 \%, \quad 32.36 \%, 12.51 \%$, $32.36 \%$ and $12.67 \%$ in zone-1, zone-2, zone-3, zone- 4 , zone5 , zone- 6 , zone- 7 and zone- 8 columns respectively when compared with the $1^{\text {st }}$ segment was removed.

Due to removal of $1^{\text {st }}$ floor column mostly effected zones are zone 1.

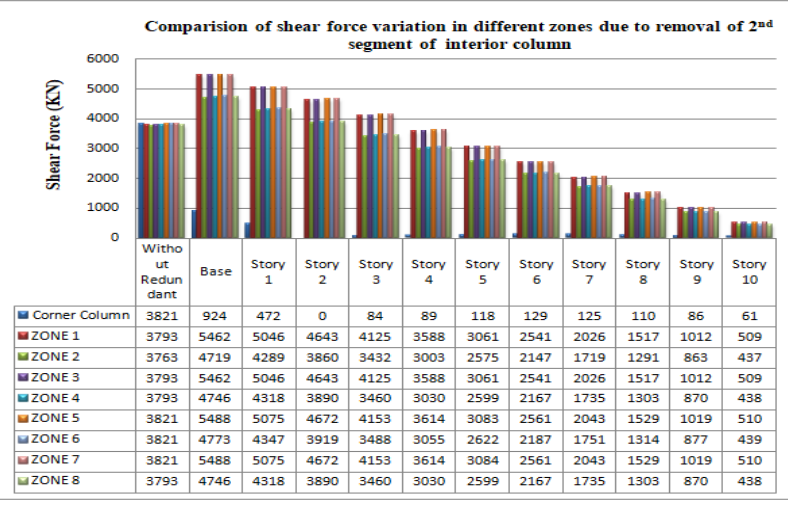

From the above graphical representation, it was observed that the axial load $\mathrm{F}_{\mathrm{y}}$ was increased to maximum by $44.01 \%$, $25.41 \%, \quad 44.01 \%, \quad 25.13 \%, \quad 43.63 \%, \quad 24.92 \%$ $43.63 \%$ and $25.13 \%$ in zone-1, zone-2, zone-3, zone-4, zone5 , zone- 6 , zone- 7 and zone- 8 columns respectively when compared with the $2^{\text {nd }}$ segment was removed.

Due to removal of $2^{\text {nd }}$ floor column mostly effected zones are zone 1 and zone 3 .

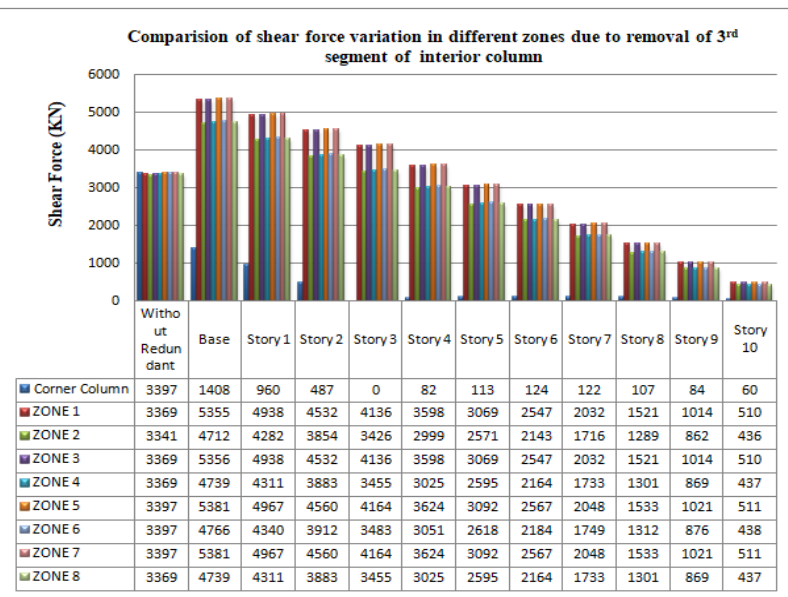

From the above graphical representation, it was observed that the axial load $\mathrm{F}_{\mathrm{y}}$ was increased to maximum by $58.95 \%$, $41.04 \%, \quad 58.98 \%, \quad 40.67 \%, \quad 58.41 \%, 40.31 \%$ $58.41 \%$ and $40.67 \%$ in zone- 1 , zone- 2 , zone- 3 , zone- 4 , zone5 , zone- 6 , zone- 7 and zone- 8 columns respectively when compared with the $3^{\text {rd }}$ segment was removed.

Due to removal of $3^{\text {rd }}$ floor column mostly effected zones are zone 1.

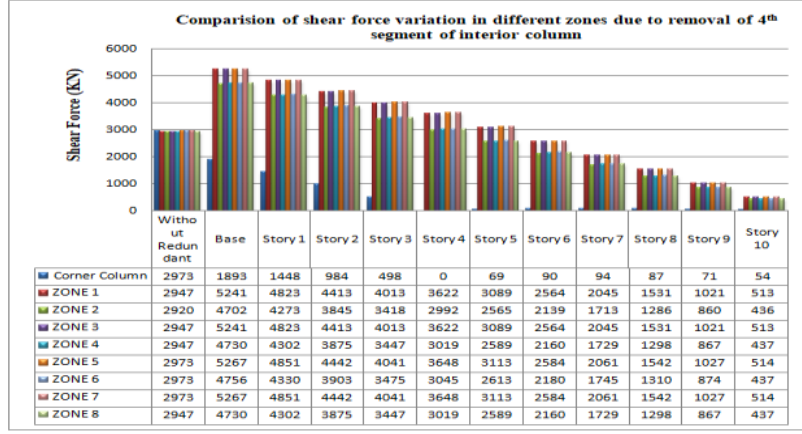

From the above graphical representation, it was observed that the axial load $\mathrm{F}_{\mathrm{y}}$ was increased to maximum by $77.85 \%, 61.03 \%, 77.85 \%, 60.51 \%, 77.17 \%, 59.98 \%$ $77.17 \%$ and $60.51 \%$ in zone-1, zone-2, zone-3, zone-4, zone5 , zone-6, zone-7 and zone- 8 columns respectively when compared with the $4^{\text {th }}$ segment was removed.

Due to removal of $4^{\text {th }}$ floor column mostly effected zones are zone 1 and zone 3.

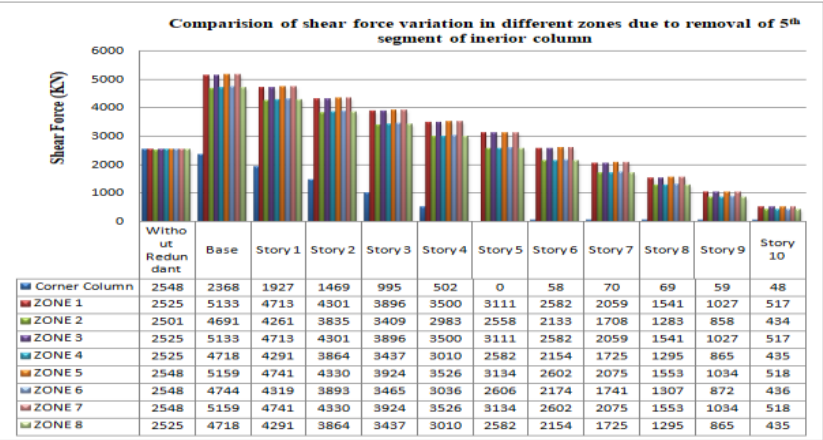

From the above graphical representation, it was observed that the axial load $\mathrm{F}_{\mathrm{y}}$ was increased to maximum by $104.28 \%, 87.57 \%, 104.28 \%, 86.86 \%, 102.48 \%, 86.19 \%$ $102.48 \%$ and $86.86 \%$ in zone-1, zone-2, zone-3, zone-4, zone- 5 , zone- 6 , zone- 7 and zone- 8 columns respectively when compared with the $5^{\text {th }}$ segment was removed.

Due to removal of $5^{\text {th }}$ floor column mostly effected zones are zone 1 and zone 3.

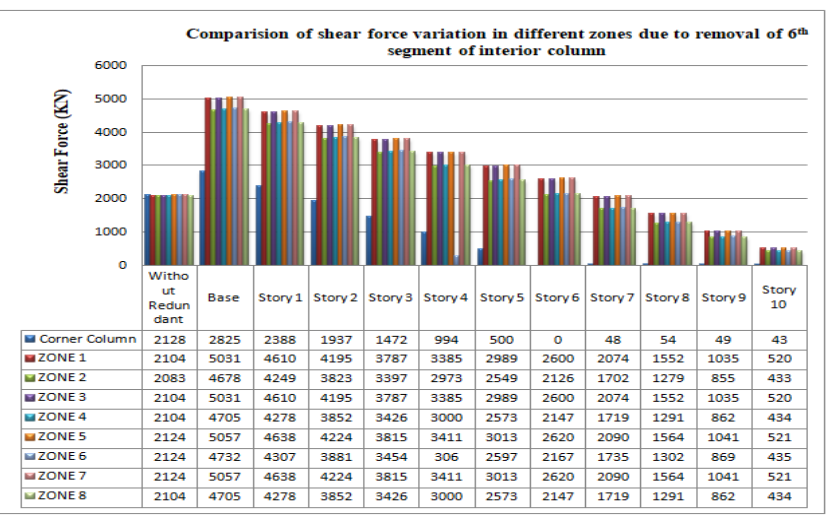

From the above graphical representation, it was observed that the axial load $\mathrm{F}_{\mathrm{y}}$ was increased to maximum by $139.12 \%, 124.58 \%, 139.12 \%, 123.63 \%, 138.09 \%, 122.79 \%$ , $138.09 \%$ and $123.63 \%$ in zone-1, zone-2, zone-3, zone-4, zone-5, zone- 6 , zone-7 and zone- 8 columns respectively when compared with the $6^{\text {th }}$ segment was removed.

Due to removal of $6^{\text {th }}$ floor column mostly effected zones are zone 1 and zone 3.

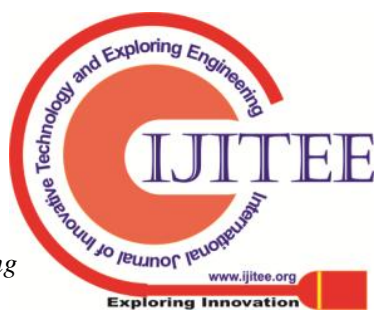




\section{Pogressive Collapse Analysis of Multi Storey (G+10) Building by Staad Pro. using Column Removal}

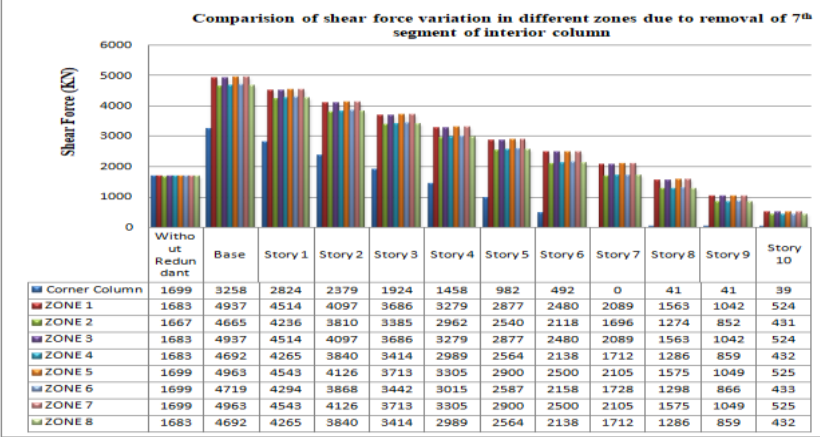

From the above graphical representation, it was observed that the axial load $\mathrm{F}_{\mathrm{y}}$ was increased to maximum by $193.35 \%, 179.85 \%, 193.35 \%, 178.79 \%, 192.12 \%, 192.12 \%$ , $192.12 \%$ and $178.79 \%$ in zone-1, zone-2, zone-3,

zone-4, zone-5, zone- 6 , zone- 7 and zone- 8 columns respectively when compared with the $7^{\text {th }}$ segment was removed.

Due to removal of $7^{\text {th }}$ floor column mostly effected zones are zone 1 and zone 3 .

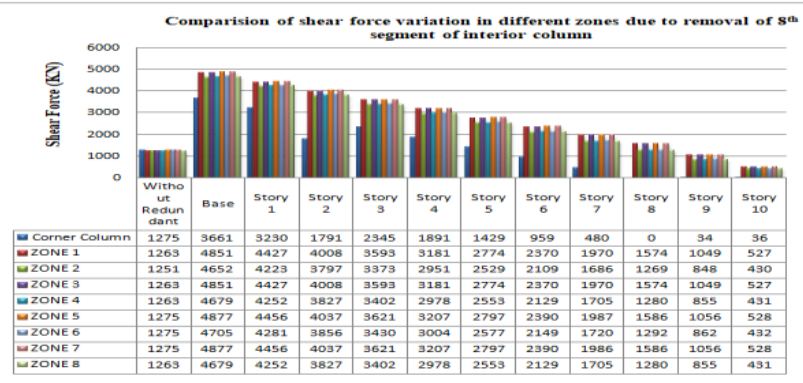

From the above graphical representation, it was observed that the axial load $\mathrm{F}_{\mathrm{y}}$ was increased to maximum by $284.09 \%, 271.87 \%, 284.09 \%, 270.47 \%, 282.51 \%, 270.47 \%$ , $282.51 \%$ and $270.47 \%$ in zone-1, zone-2, zone-3, zone-4, zone-5, zone- 6 , zone-7 and zone- 8 columns respectively when compared with the $8^{\text {th }}$ segment was removed.

Due to removal of $8^{\text {th }}$ floor column mostly effected zones are zone 1 and zone 3 .

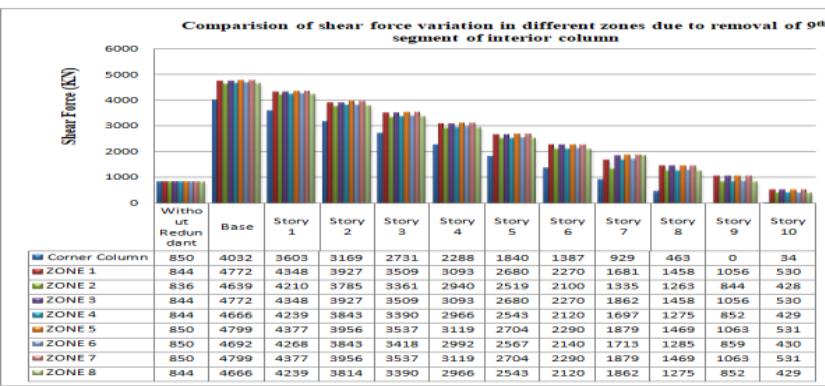

From the above graphical representation, it was observed that the axial load $\mathrm{F}_{\mathrm{y}}$ was increased to maximum by $465.41 \%, 454.91 \%, 465.41 \%, 452.85 \%, 464.59 \%, 452 \%$, $464.59 \%$ and $452.85 \%$ in zone-1, zone-2, zone-3, zone-4, zone- 5 , zone- 6 , zone- 7 and zone- 8 columns respectively when compared with the $9^{\text {th }}$ segment was removed.

Due to removal of $9^{\text {th }}$ floor column mostly effected zones are zone 1 and zone 3 .

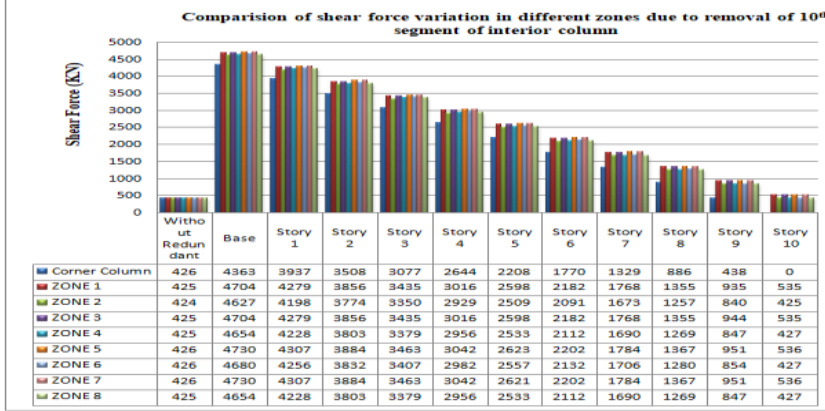

From the above graphical representation, it was observed that the axial load $\mathrm{F}_{\mathrm{y}}$ was increased to maximum by $1006.83 \%, 991.28 \%, 1006.83 \%, 995.06 \%, 1010.33 \%$, $998.60 \%, 1010.33 \%$ and $995.06 \%$ in zone-1, zone-2, zone3 , zone-4, zone-5, zone- 6 , zone- 7 and zone- 8 columns respectively when compared with the $10^{\text {th }}$ segment was removed.

Due to removal of $10^{\text {th }}$ floor column mostly effected zones are zone 5 and zone 7 .

\section{BENDING MOMENT VARIATIONS:-}

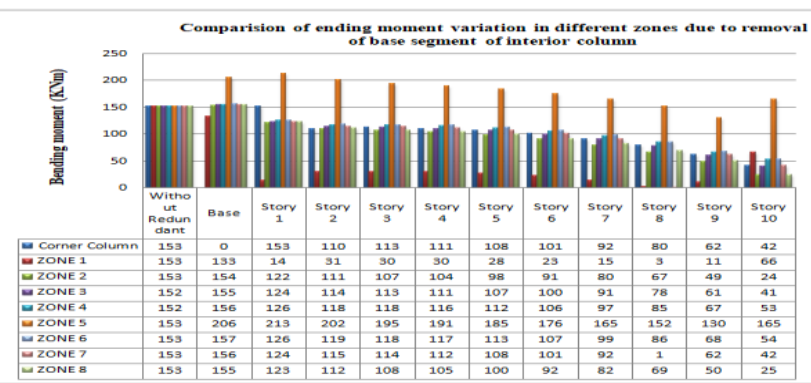

From the above graphical representation, it was observed that the bending moment $\mathrm{M}_{\mathrm{y}}$ was increased to maximum by $13.08 \%, 0.66 \%, 1.98 \%, 2.64 \%, 34.65 \%, 2.62 \%, 1.97 \%$ and $1.31 \%$ in zone-1, zone-2, zone-3, zone-4, zone-5, zone-6, zone-7 and zone- 8 columns respectively when compared with the base segment was removed.

Due to removal of base floor column mostly effected zones are zone1.

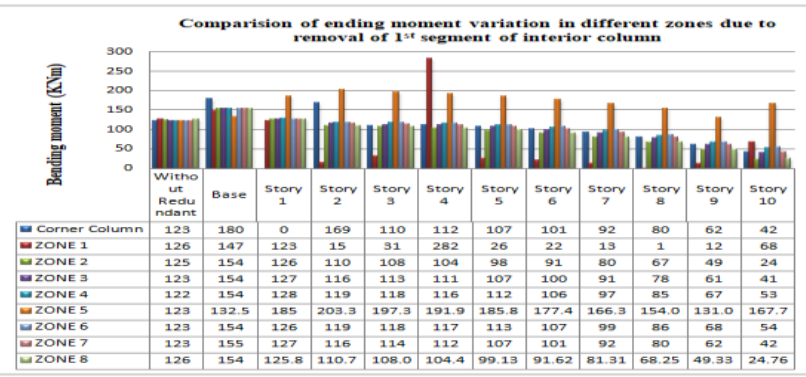

From the above graphical representation, it was observed that the bending moment $\mathrm{M}_{\mathrm{y}}$ was increased to maximum by $16.67 \%, 23.21 \%, 25.22 \%, 26.23 \%, 8.14 \%, 25.21 \%, 26.02 \%$ and $22.23 \%$ in zone-1, zone-2, zone-3, zone-4, zone-5, zone-6, zone-7 and zone- 8 columns respectively when compared with the $1^{\text {st }}$ segment was removed.

Due to removal of $1^{\text {st }}$ floor column mostly effected zones are zone7. 


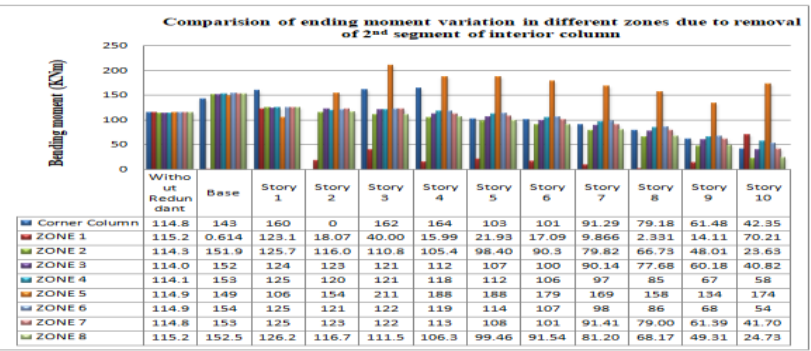

From the above graphical representation, it was observed that the bending moment $\mathrm{M}_{\mathrm{y}}$ was increased to maximum by $3.46 \%, 32.18 \%, 32.18 \%, 33.05 \%, 29.57 \%, 33.92 \%, 33.05 \%$ and $31.9 \%$ in zone-1, zone-2, zone-3, zone-4, zone-5, zone- 6 , zone-7 and zone- 8 columns respectively when compared with the $2^{\text {nd }}$ segment was removed.

Due to removal of $2^{\text {nd }}$ floor column mostly effected zones are zone6.

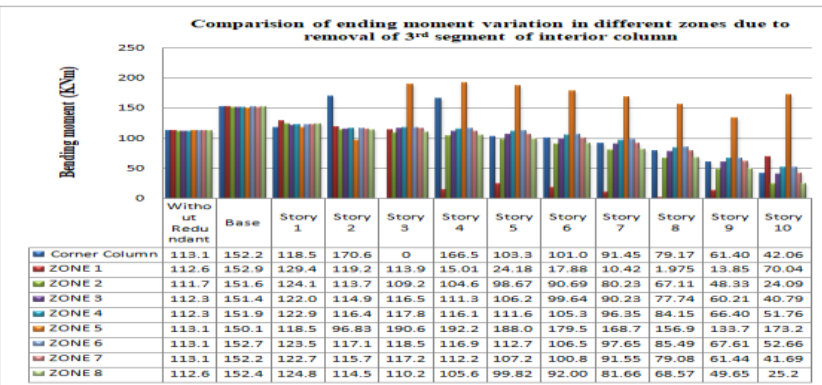

From the above graphical representation, it was observed that the bending moment $\mathrm{M}_{\mathrm{y}}$ was increased to maximum by $35.4 \%, 35.72 \%, 34.52 \%, 34.52 \%, 32.46 \%, 34.22 \%, 34.22 \%$ and $35.4 \%$ in zone-1, zone-2, zone-3, zone-4, zone-5, zone- 6 , zone- 7 and zone- 8 columns respectively when compared with the $3^{\text {rd }}$ segment was removed.

Due to removal of $3^{\text {rd }}$ floor column mostly effected zones are zone2.

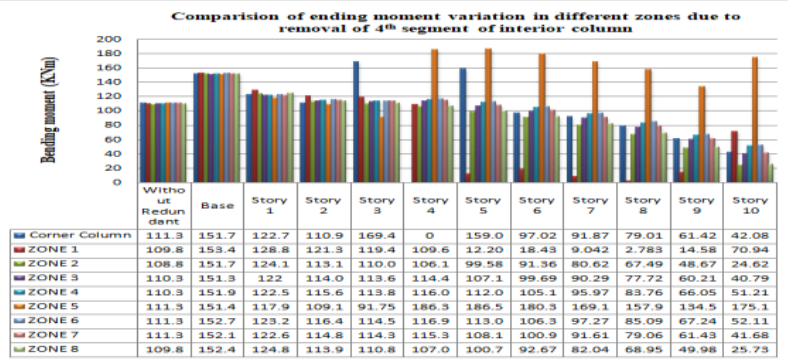

From the above graphical representation, it was observed that the bending moment $\mathrm{M}_{\mathrm{y}}$ was increased to maximum by $40 \%, 39.45 \%, 36.94 \%, 36.94 \%, 35.75 \%, 36.60 \%, 36.60 \%$ and $39.1 \%$ in zone-1, zone-2, zone-3, zone-4, zone-5, zone- 6 , zone-7 and zone- 8 columns respectively when compared with the $4^{\text {th }}$ segment was removed.

Due to removal of $4^{\text {th }}$ floor column mostly effected zones are zone1.

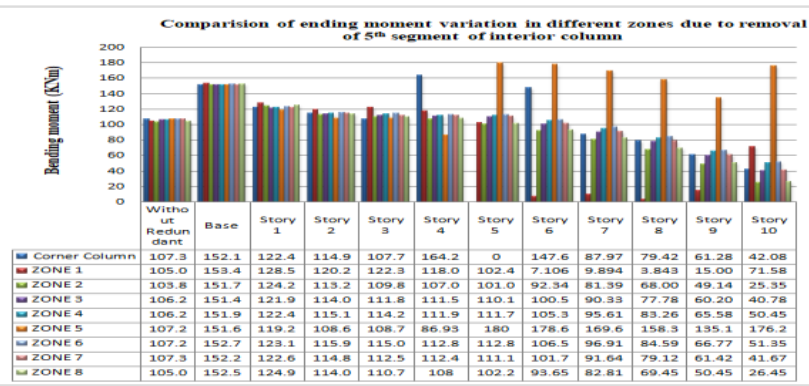

From the above graphical representation, it was observed that the bending moment $\mathrm{M}_{\mathrm{y}}$ was increased to maximum by $45.29 \%, 46.16 \%, 42.06 \%, 42.06 \%, 40.74 \%, 40.75 \%, 40.75 \%$ and $44.34 \%$ in zone-1, zone-2, zone-3, zone-4, zone-5, zone- 6 , zone-7 and zone- 8 columns respectively when compared with the $5^{\text {th }}$ segment was removed.

Due to removal of $5^{\text {th }}$ floor column mostly effected zones are zone2.

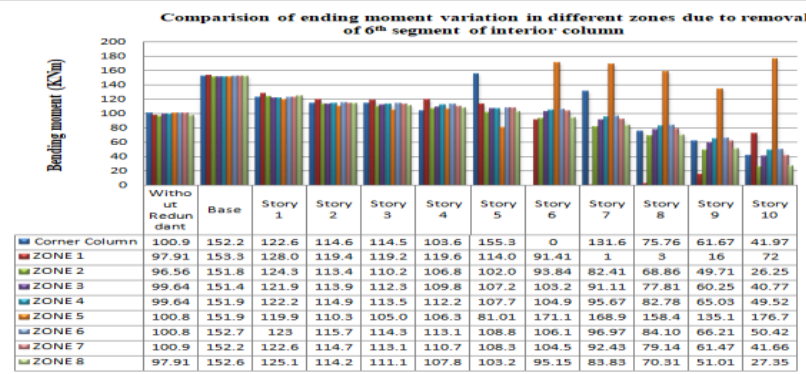

From the above graphical representation, it was observed that the bending moment $\mathrm{M}_{\mathrm{y}}$ was increased to maximum by $57.15 \%, 56.71 \%, 52 \%, 52 \%, 51.49 \%, 51.49 \%, 56.13 \%$ and $56.21 \%$ in zone-1, zone-2, zone-3, zone-4, zone-5 , zone- 6 , zone-7 and zone- 8 columns respectively when compared with the $6^{\text {th }}$ segment was removed.

Due to removal of $6^{\text {th }}$ floor column mostly effected zones are zone1.

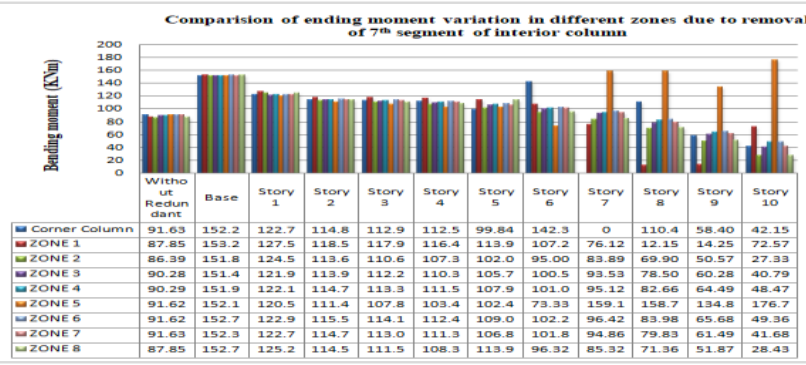

From the above graphical representation, it was observed that the bending moment $\mathrm{M}_{\mathrm{y}}$ was increased to maximum by $75 \%, 74 \%, 67.04 \%, 67.04 \%, 66.31 \%, 66.31 \%, 66.31 \%$ and $73 \%$ in zone- 1 , zone- 2 , zone- 3 , zone- 4 , zone- 5 , zone- 6 , zone-7 and zone- 8 columns respectively when compared with the $7^{\text {th }}$ segment was removed.

Due to removal of $7^{\text {th }}$ floor column mostly effected zones are zone1.

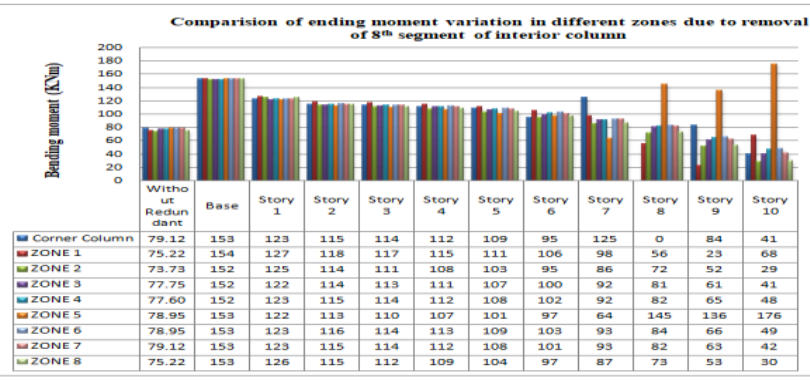

From the above graphical representation, it was observed that the bending moment $\mathrm{M}_{\mathrm{y}}$ was increased to maximum by $102.63 \%, 105.22 \%, 94.88 \%, 94.88 \%, 93.68 \%, 93.68 \%$, $91.26 \%$, and $101.32 \%$ in zone-1, zone-2, zone-3, zone- 4 , zone- 5 , zone- 6 , zone- 7 and zone- 8 columns respectively when compared with the $8^{\text {th }}$ segment was removed.

Due to removal of $8^{\text {th }}$ floor column mostly effected zones are zone2. 


\section{Pogressive Collapse Analysis of Multi Storey (G+10) Building by Staad Pro. using Column Removal}

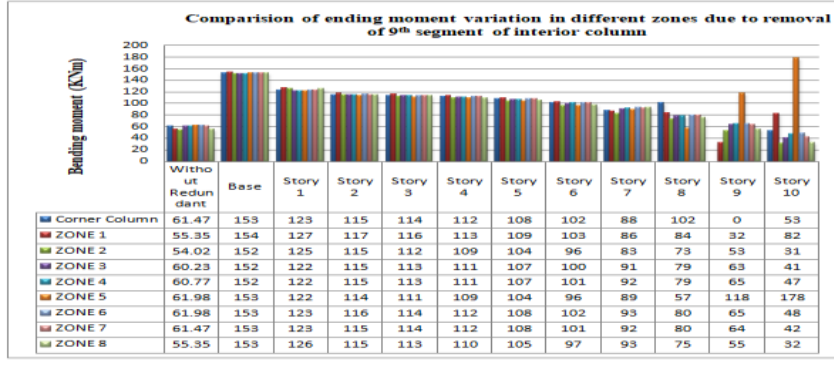

From the above graphical representation, it was observed that the bending moment $\mathrm{M}_{\mathrm{y}}$ was increased to maximum by $175 \%, 186.54 \%, 149.18 \%, 149.18 \%, 146.78 \%, 146.78 \%$, $146.76 \%$ and $173.22 \%$ in zone-1, zone-2, zone-3, zone-4, zone-5, zone-6, zone-7 and zone- 8 columns respectively when compared with the $9^{\text {th }}$ segment was removed.

Due to removal of $9^{\text {th }}$ floor column mostly effected zones are zone 2 .

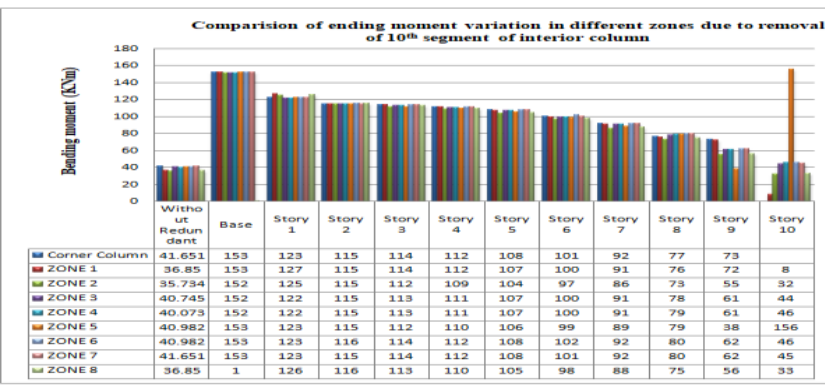

From the above graphical representation, it was observed that the bending moment $\mathrm{M}_{\mathrm{y}}$ was increased to maximum by $264.29 \%, 313.52 \%, 322.23 \%, 265.29 \%, 270.73 \%, 273.17 \%$, $264.29 \%$ and $97.23 \%$ in zone-1, zone-2, zone-3, zone-4, zone- 5 , zone- 6 , zone- 7 and zone- 8 columns respectively when compared with the $10^{\text {th }}$ segment was removed.

Due to removal of $10^{\text {th }}$ floor column mostly effected zones are zone 3 .

\section{CONCLUSION}

After doing progressive Analysis following conclusion were made:

- It was observed that there is continuous decrease in the value from bottom Story to top Story, which concludes that the failure is more at bottom Story than top Story.

- It was also found that by removing of corner columns individually, the values are decreasing according to the bottom to top story that concludes for Corner Column Removal Case, beam in the base $, 1^{\text {st }}, 2^{\text {nd }}, 3^{\text {rd }}, 4^{\text {th }}, 5^{\text {th }}, 6^{\text {th }}$ story face progressive collapse but from $7^{\text {th }}$ to $10^{\text {Th }}$ Story is safe against Progressive Collapse.

- It was also observed that during removal of Exterior Column Removal case, beams in $1^{\text {st }}$ and $5^{\text {th }}$ story of building more affected by progressive collapse rather than the top stories.

- It was also observed that in Case of Interior Column Removal Case, beam in $3^{\text {rd }}, 4^{\text {th }}, 5^{\text {th }}, 8^{\text {th }}, 9^{\text {th }}$ and $10^{\text {th }}$ Story were safe against Progressive Collapse.

- The Special Moment Resistance Frame (SMRF) by IS 456:2000 does not provide resistance to progressive Collapse. This is because of that SMRF is designed for
Lateral loads and in Progressive Collapse the Failure is due to gravity Loads.

\section{REFERENCES}

1. General Services Administration (GSA). (2003).Progressive collapse analysis and design guidelines for New federal office buildings and major modernization projects, GSA.

2. Mr. S. Mahesh, Mr. Dr.B., PandurangaRao "Comparison of analysis and design of regular and irregular configuration of multi-Story building in various seismic zones and various types of soils using ETABS and STAAD" in Journal of Mechanical and Civil Engineering (IOSR-JMCE),e-ISSN: 2278-1684,p-ISSN: 2320-334X, Volume 11, Issue 6 Ver. I (Nov- Dec. 2014), PP 45-52.

3. Meng-Hao Tsai, Tsuei-Chiang Huang (2011)." Progressive Collapse Analysis of an RC Building with Exterior Non-Structural Walls" .Procedia Engineering 14 (2011) 377

4. Giriunas (2009), "Progressive Collapse Analysis of an Existing Building," Ohio state University.

5. Usmanllyas, S H Farooq, I. Shahid and M. Ilyas, "Progressive Collapse of Reinforced Concrete Frame Structure under Column Damage Consideration", Pak. J. Engg. \& Appl. Sci. Vol. 16, Jan., 2015 (p. 61-66).

\section{AUTHORS PROFILE}

SURAPU RAMLAL, M.Tech(Ph.D), Department of Civil engineering, HOD, Associate Professor,Aditya Institute of Technology \& Management, Tekkali, Amdhrapradesh.

PONNANA RAMPRASAD, M.Tech(Ph.D), Department of Civil engineering, Assistant Professor, Aditya Institute of Technology \& Management, Tekkali, Amdhrapradesh.

Dr.CH VASUDEVARAO, Ph.D, Department of Civil engineering, Associate Professor, Aditya Institute of Technology \& Management, Tekkali, Amdhrapradesh. 